\title{
Evidence-Based Guidelines for Cardiovascular Disease Prevention in Women
}

\author{
Expert Panel/Writing Group* \\ Lori Mosca, MD, PhD (Chair) ${ }^{\dagger}$; Lawrence J. Appel, MD ${ }^{\dagger}$; Emelia J. Benjamin, MD ${ }^{\dagger}$; \\ Kathy Berra, MSN, ANP ${ }^{\dagger \S}$; Nisha Chandra-Strobos, $\mathrm{MD}^{\dagger}$; Rosalind P. Fabunmi, $\mathrm{PhD}^{\dagger}$; \\ Deborah Grady, MD, MPH ${ }^{\text {If; }}$ Constance K. Haan, MD ${ }^{\| \prime}$; Sharonne N. Hayes, MD; \\ Debra R. Judelson, $\mathrm{MD}^{\#}$; Nora L. Keenan, $\mathrm{PhD}^{\dagger \dagger}$; Patrick McBride, MD, $\mathrm{MPH}^{\dagger}$; \\ Suzanne Oparil, $\mathrm{MD}^{\dagger}$; Pamela Ouyang, $\mathrm{MD}^{\dagger}$; Mehmet C. Oz, MD \\ Michael E. Mendelsohn, MD ${ }^{\dagger}$, Richard C. Pasternak, MD \\ Rose Marie Robertson, $\mathrm{MD}^{\dagger}$; Karin Schenck-Gustafsson, $\mathrm{MD}, \mathrm{PhD}^{\dagger}$; Cathy A. Sila, $\mathrm{MD}^{\dagger}$; \\ Sidney C. Smith, Jr, MD ${ }^{\text {qti }}$; George Sopko, MD, MPH*; Anne L. Taylor, MD**; \\ Brian W. Walsh, MD ${ }^{\|}$; Nanette K. Wenger, MD ${ }^{\dagger}$; Christine L. Williams, MD, MPH ${ }^{\dagger}$
}

\begin{abstract}
*Representing the following participating organizations and major cosponsors: the American Heart Association†; American College of Cardiologył; American College of Nurse Practitioners§; American College of Obstetricians and Gynecologists\|; American College of PhysiciansI; American Medical Women's Association\#; Association of Black Cardiologists**; Centers for Disease Control and Prevention††; National Heart, Lung and Blood Instituteł+; Office of Research on Women's Health§§; Society of Thoracic Surgeons|||; and World Heart FederationIIII.
\end{abstract}

In addition, endorsed by: American Academy of Physician Assistants; American Association for Clinical Chemistry; American Association of Cardiovascular and Pulmonary Rehabilitation; American Diabetes Association; American Geriatrics Society; American Society for Preventive Cardiology; American Society of Echocardiography; American Society of Nuclear Cardiology; Association of Women's Health, Obstetric and Neonatal Nurses; Canadian Women's Health Network; Jacobs Institute for Women's Health; Black Women's Health Imperative; National Women's Health Resource Center; The North American Menopause Society; Partnership for Gender-Specific Medicine; Preventive Cardiovascular Nurses Association;

Sister to Sister: Everyone Has a Heart Foundation, Inc.; Society for Women's Health Research; Society of Geriatric Cardiology; The Mended Hearts Inc; WomenHeart the National Coalition for Women With Heart Disease; and Women's Health Research Center.

$\mathrm{S}_{\mathrm{i}}^{\mathrm{s}}$ ignificant advances in our knowledge about interventions to prevent cardiovascular disease (CVD) have occurred since publication of the first female-specific recommendations for preventive cardiology in $1999 .{ }^{1}$ Despite researchbased gains in the treatment of CVD, it remains the leading killer of women in the United States and in most developed areas of the world..$^{2-3}$ In the United States alone, more than one half million women die of CVD each year, exceeding the number of deaths in men and the next 7 causes of death in women combined. This translates into approximately 1 death every minute. ${ }^{2}$ Coronary heart disease (CHD) accounts for the majority of CVD deaths in women, disproportionately afflicts racial and ethnic minorities, and is a prime target for prevention. ${ }^{1-2}$ Because CHD is often fatal, and because nearly two thirds of women who die suddenly have no previously recognized symptoms, it is essential to prevent CHD. ${ }^{2}$ Other forms of atherosclerotic/thrombotic CVD, such as cerebrovascular disease and peripheral arterial disease, are critically important in women. Strategies known to reduce the burden of CHD may have substantial benefits for the prevention of noncoronary atherosclerosis, although they have been studied less extensively in some of these settings.

The American Heart Association makes every effort to avoid any actual or potential conflicts of interest that may arise as a result of an outside relationship or a personal, professional, or business interest of a member of the writing panel. Specifically, all members of the writing group are required to complete and submit a Disclosure Questionnaire showing all such relationships that might be perceived as real or potential conflicts of interest.

This statement was approved by the American Heart Association Science Advisory and Coordinating Committee on December 1, 2003. A single reprint is available by calling 800-242-8721 (US only) or writing the American Heart Association, Public Information, 7272 Greenville Ave, Dallas, TX 75231-4596. Ask for reprint No. 71-0276. To purchase additional reprints: up to 999 copies, call 800-611-6083 (US only) or fax 413-665-2671; 1000 or more copies, call 410-528-4121, fax 410-528-4264, or e-mail kgray@lww.com. To make photocopies for personal or educational use, call the Copyright Clearance Center, 978-750-8400.

(Circulation. 2004;109:672-693.)

The online-only Data Supplement is available at http://www.circulationaha.org.

(C) 2004 American Heart Association, Inc. 
In the wake of the reports of the Women's Health Initiative and the Heart and Estrogen/Progestin Replacement Study (HERS), which unexpectedly showed that combination hormone therapy was associated with adverse CVD effects, there is a heightened need to critically review and document strategies to prevent CVD in women. ${ }^{4-7}$ These studies underscore the importance of evidence-based practice for chronic disease prevention. Optimal translation and implementation of science to improve preventive care should include a rigorous process of evaluation and clear communication about the quantity and quality of evidence used to support clinical recommendations. Recently, there has been an increase in the number and proportion of women that have participated in clinical trials, although many early CVD prevention trials did not fully include women and other important subpopulations. ${ }^{8}$ Therefore, it is important to consider the full range of available evidence, including data on men as appropriate, to develop recommendations for diverse populations of women. Furthermore, because many patients seen in clinical practice may have characteristics that are not similar to those of clinical trial participants, it is necessary to draw inferences about the likelihood that data will generalize from research to clinical settings.

The objective of this collaborative effort was to develop the first set of evidence-based guidelines for the prevention of CVD in adult women with a broad range of cardiovascular risk. The technology for identifying CVD in its earliest stages has improved over the past decade, and this has led to a blurring of the distinction between primary and secondary prevention. The concept of CVD as a categorical, "have-orhave-not" condition has been replaced with a growing appreciation for the existence of a continuum of CVD risk. Table 1 illustrates a spectrum of CVD, showing risk groups defined by their absolute probability of having a coronary event in 10 years according to the Framingham Risk Score for women. ${ }^{9}$ Clinical diagnoses and scenarios that broadly group women into categories of high, intermediate, and lower risk also are provided. This scheme allows healthcare providers to match the intensity of risk intervention to the baseline level of CVD risk. A scoring sheet for use in clinical practice to calculate absolute 10-year CHD risk in women is provided in Appendix I. The recommendations herein are designed to assist healthcare providers in optimizing CVD preventive care for all women age 20 years and older. Implementation of these guidelines may differ among countries and regions for cultural, medical, and economic reasons. In addition, application of these guidelines should also take into consideration individual factors such as frailty and life expectancy.

\section{Methods}

\section{Selection of Expert Panel Members}

The leadership of each of the 13 American Heart Association (AHA) Scientific Councils was asked to nominate a recognized expert in CVD prevention who had particular knowledge about women. The president of the AHA appointed at-large members to fill gaps in specific areas of expertise. The AHA Manuscript Oversight Committee approved the chair of the Expert Panel. On the basis of recommendations of the AHA Expert Panel, major professional or government organizations with a mission consistent with CVD prevention were solicited to serve as cosponsors and were asked to nominate 1 representative with full voting rights to serve on the Expert Panel. Panelists also suggested diverse professional and community organizations to endorse the final document after its approval by the AHA Science Advisory Coordinating Committee and cosponsoring organizations.

TABLE 1. Spectrum of CVD Risk in Women

\begin{tabular}{|c|c|c|}
\hline Risk Group & $\begin{array}{l}\text { Framingham Global Risk } \\
\text { (10-y Absolute CHD Risk) }\end{array}$ & Clinical Examples \\
\hline High risk & $>20 \%$ & $\begin{array}{l}\text { - Established CHD } \\
\text { - Cerebrovascular disease* } \\
\text { - Peripheral arterial disease } \\
\text { - Abdominal aortic aneurysm } \\
\text { - Diabetes mellitus } \\
\text { - Chronic kidney disease } †\end{array}$ \\
\hline Intermediate risk & $10 \%$ to $20 \%$ & $\begin{array}{l}\text { - Subclinical CVD } ¥ \text { (eg, coronary calcification) } \\
\text { - Metabolic syndrome } \\
\text { - Multiple risk factors§ } \\
\text { - Markedly elevated levels of a single risk factor\| } \\
\text { - First-degree relative(s) with early-onset (age: }<55 \text { y in men and }<65 \text { y in women) } \\
\text { atherosclerotic CVD }\end{array}$ \\
\hline Lower risk & $<10 \%$ & - May include women with multiple risk factors, metabolic syndrome, or 1 or no risk factors \\
\hline Optimal risk & $<10 \%$ & - Optimal levels of risk factors and heart-healthy lifestyle \\
\hline
\end{tabular}

CHD indicates coronary heart disease; CVD, cardiovascular disease.

${ }^{*}$ Cerebrovascular disease may not confer high risk for $\mathrm{CHD}$ if the affected vasculature is above the carotids. Carotid artery disease (symptomatic or asymptomatic with $>50 \%$ stenosis) confers high risk.

†As chronic kidney disease deteriorates and progresses to end-stage kidney disease, the risk of CVD increases substantially.

¥Some patients with subclinical CVD will have $>20 \% 10$-year CHD risk and should be elevated to the high-risk category.

§Patients with multiple risk factors can fall into any of the 3 categories by Framingham scoring.

$\|$ Most women with a single, severe risk factor will have a 10 -year risk $<10 \%$. 
TABLE 2. Summary of Articles Identified From Systematic Literature Review by Topic

\begin{tabular}{|c|c|c|c|c|}
\hline Topic & $\begin{array}{l}\text { Abstracts } \\
\text { Identified }\end{array}$ & $\begin{array}{l}\text { Articles Included } \\
\text { for Full-Text } \\
\text { Screening }\end{array}$ & $\begin{array}{l}\text { Meta-Analyses } \\
\text { Identified }\end{array}$ & $\begin{array}{c}\text { Articles Included } \\
\text { for Evidence } \\
\text { Tables }\end{array}$ \\
\hline Hyperlipidemia & 339 & 119 & 5 & 40 \\
\hline Physical activity & $950^{*}$ & 95 & 6 & 52 \\
\hline Tobacco use & 1341 & 127 & 6 & 16 \\
\hline Antiplatelet therapy & 753 & 155 & 12 & 31 \\
\hline Blood pressure management & 273 & 112 & 16 & 31 \\
\hline$\beta$-Blocker therapy & 845 & 136 & 12 & 30 \\
\hline Cardiac rehabilitation & $950^{*}$ & 69 & 4 & 19 \\
\hline ACE/ARB therapy & 371 & 48 & 7 & 21 \\
\hline Weight management & 158 & 25 & 1 & 6 \\
\hline Diabetes & 229 & 56 & 2 & 8 \\
\hline Hormone replacement therapy & 373 & 93 & 5 & 41 \\
\hline Diet modification & 425 & 89 & 4 & 68 \\
\hline Warfarin in atrial fibrillation & 242 & 49 & 6 & 11 \\
\hline Aspirin for primary prevention & 25 & 15 & 3 & 10 \\
\hline Depression therapy & 45 & 5 & 0 & 2 \\
\hline Antioxidant supplementation & 220 & 43 & 0 & 16 \\
\hline 0mega-3 fatty acid supplementation & 169 & 45 & 2 & 8 \\
\hline Folic acid supplementation & 69 & 10 & 1 & 3 \\
\hline Total $†$ & 6819 & 1279 & 92 & 399 \\
\hline
\end{tabular}

ACE indicates angiotensin-converting enzyme; ARB, angiotensin receptor blocker.

*Physical activity and cardiac rehabilitation were combined during the initial literature search. This number reflects the total number of abstracts identified as physical activity OR cardiac rehabilitation.

†Total numbers reflect unique articles. Actual sum of the individual recommendation numbers are higher than total due to the inclusion of some articles under more than one recommendation. The exception is the total articles included for evidence tables, which reflects the number of tables that appear in the report.

\section{Selection of Topics and Candidate Recommendations}

The Expert Panel reviewed previously published AHA recommendations for the primary and secondary prevention of CVD and discussed and debated topics that were timely, with the goal of developing a set of candidate recommendations for searching and rating. ${ }^{1,10-11} \mathrm{~A}$ list of preselected recommendations was circulated to the panel, and experts were asked to independently rate the priority of the recommendation and suggest modifications to the wording. Recommendations were then selected for the systematic literature search.

\section{Systematic Search and Summary of Data}

Inclusion and exclusion criteria for studies to be evaluated as part of the evidence-rating process were established according to the Expert Panel recommendation to focus on major CVD clinical end points (death, myocardial infarction, stroke, revascularization procedure, congestive heart failure, or a composite CVD end point) in high-quality studies. The importance of other outcomes, such as quality of life and resource utilization, was recognized, but these were not feasible to include in this version. The purpose of the clinical recommendations is to provide guidance with regard to risk-reducing interventions; therefore, the panel supported the inclusion of studies that were interventional rather than etiologic in nature. For example, studies of the impact of weight loss on major clinical CVD outcomes were included but not studies that simply related obesity to CVD.
Inclusion criteria were randomized clinical trials or large prospective cohort studies ( $>1000$ subjects) with CVD risk-reducing interventions evaluated. Also, meta-analyses that used a quantitative systematic review process were included. All studies had to have at least 10 cases of major clinical CVD end points reported. Studies with surrogate end points were excluded unless they met the minimum number of outcome events. Studies meeting the above criteria were included whether or not there were female participants.

The systematic search was conducted by the Duke Center for Clinical Health Policy Research, Durham, NC. Search terms were constructed for each clinical recommendation, with an "explode" term to include related articles. Three databases were searched electronically on OVID, including Medline (1966 through July 3, 2003), the Cumulative Index to Nursing \& Allied Health (CINAHL) (1982 through July 3, 2003), and PsycInfo (1872 through July 3, 2003). More than 99\% of the studies were located in Medline. Nearly 7000 titles and abstracts identified through the systematic search were reviewed to exclude those that did not meet obvious eligibility criteria or were not available in English. More than 1200 articles were obtained for full-text screening and reviewed for inclusion/exclusion criteria. A standardized abstraction form was completed to document the study design, end points, and decision to include or exclude. Table 2 lists the number of articles included/excluded for each category of recommendation. 
TABLE 3. Classification and Levels of Evidence

\begin{tabular}{ll}
\hline & \multicolumn{1}{c}{ Strength of Recommendation } \\
\hline $\begin{array}{l}\text { Classification } \\
\text { Class I }\end{array}$ & $\begin{array}{l}\text { Intervention is useful and effective } \\
\text { Weight of evidence/opinion is in favor of } \\
\text { usefulness/efficacy } \\
\text { Usefulness/efficacy is less well established by } \\
\text { evidence/opinion } \\
\text { Intervention is not useful/effective and may be } \\
\text { harmful }\end{array}$ \\
Level of Evidence & $\begin{array}{l}\text { Sufficient evidence from multiple randomized } \\
\text { trials } \\
\text { B }\end{array}$ \\
Limited evidence from single randomized trial or \\
other nonrandomized studies \\
Based on expert opinion, case studies, or \\
standard of care
\end{tabular}

Included articles were abstracted for more detailed information on a standardized form that included study type, number of participants (\% female) at baseline, population characteristics (primary prevention, secondary prevention, or mixed), mean age (age range), percentage diabetic, percentage white, intervention(s) (for drug trials, information was listed about dose, schedule, and duration), primary outcomes including numbers of events, subgroup analysis of clinical end points in women (if analysis available), and comments about important methodological or quality issues.

Expert Panel members reviewed the summary evidence tables for completeness. Tables were updated with publications that were inadvertently omitted or included during the systematic search to comprise the final evidence tables. In addition, results of trials or meta-analyses published subsequent to the systematic search that met inclusion criteria were made available to the Expert Panel. A complete listing of references reviewed by the Expert Panel and used to compile the evidence summary tables is listed in Appendix II. The evidence summary tables are located in an online-only Data Supplement at http://www.circulationaha.org.

\section{Evidence Rating System}

Two primary reviewers from the Expert Panel were assigned to each candidate recommendation to propose an initial evidence rating and suggest modifications to wording on the basis of the results of the systematic evidence search. A series of conference calls was held to discuss the rating and revised wording of recommendations. Each expert received a final copy of the evidence tables and voted independently on the strength of the recommendation (Class I, IIa, IIb, or III) and level of evidence (A, B, or C) as outlined in Table 3. Class I interventions should be administered unless contraindicated. Class III interventions should not be administered for CVD prevention. The rationale for the rating system is based on methods used in AHA/ American College of Cardiology clinical practice guidelines as described. ${ }^{12}$ The experts also evaluated the likelihood that data from men would generalize to women with regard to each specific risk-reducing intervention (1, very likely; 2 , somewhat likely; 3, unlikely; and 0, unable to project). Criteria to determine generalizability were based on factors such as differences in the epidemiology and pathophysiology of CVD between men and women (eg, the ratio of hemorrhagic stroke to coronary events may alter the risk-to-benefit ratio of aspirin in primary prevention for women versus men). The final rating of evidence was determined by a majority vote.

\section{Clinical Recommendations}

Evidence-based recommendations for the prevention of CVD in women are listed in Table 4. Each recommendation is accompanied by the strength of recommendation, level of evidence to support it, and the generalizability index. The strength of the recommendation is based on not only the level of evidence to support a clinical recommendation, but also on factors such as feasibility of conducting randomized controlled trials in women. Recommendations are grouped in the following categories: lifestyle interventions; major risk factor interventions; atrial fibrillation/stroke prevention; preventive drug interventions; and a Class III category, where routine intervention for CVD prevention is not recommended.

Several lifestyle interventions were rated as Class I recommendations, although the supporting evidence was in many cases classified as level B. These decisions reflect the availability of observational studies as evidence to support the recommendation, as well as ethical issues that preclude conducting randomized controlled trials of certain lifestyle interventions. For example, the Expert Panel regarded smoking cessation as a top priority in clinical practice and suggested that the absence of trial data should not preclude a strong emphasis on clinician interventions to help women stop smoking. More detailed information on how to treat tobacco dependence is available at http://www.surgeongeneral.gov/tobacco/treating_tobacco_use.pdf (Table 5).

Lifestyle interventions received Class I recommendations from the panel not only because of their potential to reduce clinical CVD, but also because heart-healthy lifestyles may prevent the development of major risk factors for CVD. ${ }^{13}$ Prevention of the development of risk factors through a positive lifestyle approach may minimize the need for more intensive intervention in the future.

Although evidence to support a clinical benefit for CVD event reduction was limited with some interventions (eg, treatment of depression), there may be other important benefits associated with these therapies that are reflected in the strength of the recommendation, such as improved quality of life. Behavioral interventions may have benefits that are not captured by our stringent outcome criteria for clinical CVD events. Weight management via lifestyle and behavioral approaches was rated as a Class I recommendation, level B. The panel suggested there was insufficient evidence to rate more aggressive medical and surgical approaches that generally are limited to a small subset of women. 


\section{TABLE 4. Clinical Recommendations}

\section{Lifestyle interventions}

\section{Cigarette smoking}

Consistently encourage women not to smoke and to avoid environmental tobacco. (Class I, Level B) $)_{\mathrm{Gl}=1}$

\section{Physical activity}

Consistently encourage women to accumulate a minimum of 30 minutes of moderate-intensity physical activity (eg, brisk walking) on most, and preferably all, days of the week. (Class I, Level B) Gl=1 $_{1}$

\section{Cardiac rehabilitation}

Women with a recent acute coronary syndrome or coronary intervention, new-onset or chronic angina should participate in a comprehensive risk-reduction regimen, such as cardiac rehabilitation or a physician-guided home- or community-based program. (Class I, Level B) $)_{\mathrm{Gl}=2}$

\section{Heart-healthy diet}

Consistently encourage an overall healthy eating pattern that includes intake of a variety of fruits, vegetables, grains, low-fat or nonfat dairy products, fish, legumes, and sources of protein low in saturated fat (eg, poultry, lean meats, plant sources). Limit saturated fat intake to $<10 \%$ of calories, limit cholesterol intake to $<300 \mathrm{mg} / \mathrm{d}$, and limit intake of trans fatty acids. (Class I, Level B $)_{\mathrm{Gl}=1}$

\section{Weight maintenance/reduction}

Consistently encourage weight maintenance/reduction through an appropriate balance of physical activity, caloric intake, and formal behavioral programs when indicated to maintain/achieve a BMI between 18.5 and $24.9 \mathrm{~kg} / \mathrm{m}^{2}$ and a waist circumference $<35$ in. (Class I, Level B) $\mathrm{Gl}=1$

\section{Psychosocial factors}

Women with CVD should be evaluated for depression and refer/treat when indicated. (Class Ila, Level $\mathrm{B})_{\mathrm{Gl}=2}$

\section{Omega 3 fatty acids}

As an adjunct to diet, omega 3 fatty-acid supplementation may be considered in high-risk* women. (Class Ilb, Level $\mathrm{B})_{\mathrm{Gl}=2}$

\section{Folic acid}

As an adjunct to diet, folic acid supplementation may be considered in high-risk* women (except after revascularization procedure) if a higher-than-normal level of homocysteine has been detected. (Class Illb, Level B) Gl $=2$

\section{Major risk factor interventions}

\section{Blood pressure-lifestyle}

Encourage an optimal blood pressure of $<120 / 80 \mathrm{~mm} \mathrm{Hg}$ through lifestyle approaches. (Class I, Level B) $)_{\mathrm{Gl}=1}$

\section{Blood pressure-drugs}

Pharmacotherapy is indicated when blood pressure is $\geq 140 / 90 \mathrm{~mm} \mathrm{Hg}$ or an even lower blood pressure in the setting of blood pressure-related target-organ damage or diabetes. Thiazide diuretics should be part of the drug regimen for most patients unless contraindicated. (Class I, Level A) Gl $=1_{1}$

\section{Lipid, lipoproteins}

Optimal levels of lipids and lipoproteins in women are LDL-C $<100 \mathrm{mg} / \mathrm{dL}, \mathrm{HDL}-\mathrm{C}>50 \mathrm{mg} / \mathrm{dL}$, triglycerides $<150 \mathrm{mg} / \mathrm{dL}$, and non-HDL-C (total cholesterol minus HDL cholesterol) $<130 \mathrm{mg} / \mathrm{dL}$ and should be encouraged through lifestyle approaches. (Class I, Level B) $\mathrm{Gl}_{1=1}$

\section{Lipids-diet therapy}

In high-risk women or when LDL-C is elevated, saturated fat intake should be reduced to $<7 \%$ of calories, cholesterol to $<200 \mathrm{mg} / \mathrm{d}$, and trans fatty acid intake should be reduced. (Class I, Level B) $)_{\mathrm{Gl}=1}$

\section{Lipids-pharmacotherapy-high risk*}

Initiate LDL-C-lowering therapy (preferably a statin) simultaneously with lifestyle therapy in high-risk women with LDL-C $\geq 100 \mathrm{mg} / \mathrm{dL}$ (Class I, Level A) Gl=1 , and initiate statin therapy in high-risk women with an LDL-C $<100 \mathrm{mg} / \mathrm{dL}$ unless contraindicated (Class I, Level B) Gl $=1$. $^{2}$

Initiate niacin§ or fibrate therapy when HDL-C is low, or non-HDL-C elevated in high-risk women. (Class I, Level B) ${ }_{\mathrm{Gl}=1}$

Gl indicates generalizability index; LDL-C, low-density lipoprotein cholesterol; HDL-C, high-density lipoprotein cholesterol; ACE, angiotensin-converting enzyme; and ARB, angiotensin receptor blocker.

*High risk is defined as CHD or risk equivalent, or 10 -year absolute $\mathrm{CHD}$ risk $>20 \%$.

tIntermediate risk is defined as 10-year absolute CHD risk 10\% to $20 \%$.

fLower risk is defined as 10-year absolute CHD risk $<10 \%$.

$\S$ Dietary supplement niacin must not be used as a substitute for prescription niacin, and over-the-counter niacin should only be used if approved and monitored by a physician. 


\section{TABLE 4. Continued}

\section{Lipids—pharmacotherapy—intermediate risk†}

Initiate LDL-C-lowering therapy (preferably a statin) if LDL-C level is $\geq 130 \mathrm{mg} / \mathrm{dL}$ on lifestyle therapy (Class I, Level $A)_{\mathrm{Gl}=1}$, or niacin§ or fibrate therapy when HDL-C is low or non-HDL-C elevated after LDL-C goal is reached. (Class I, Level $B)_{G \mid=1}$

\section{Lipids—pharmacotherapy—lower riskł}

Consider LDL-C-lowering therapy in low-risk women with 0 or 1 risk factor when LDL-C level is $\geq 190 \mathrm{mg} / \mathrm{dL}$ or if multiple risk factors are present when LDL-C is $\geq 160 \mathrm{mg} / \mathrm{dL}$ (Class Ila, Level B) or niacin§ or fibrate therapy when HDL-C is low or non-HDL-C elevated after LDL-C goal is reached. (Class lla, Level B) $)_{\mathrm{Gl}=1}$

\section{Diabetes}

Lifestyle and pharmacotherapy should be used to achieve near normal $\mathrm{HbA}_{1 \mathrm{C}}(<7 \%)$ in women with diabetes. (Class I, Level $\mathrm{B})_{\mathrm{Gl}=1}$

\section{Preventive drug interventions}

\section{Aspirin-high risk*}

Aspirin therapy (75 to $162 \mathrm{mg}$ ), or clopidogrel if patient is intolerant to aspirin, should be used in high-risk women unless contraindicated. (Class I, Level A) $)_{\mathrm{Gl}=1}$

\section{Aspirin-intermediate risk†}

Consider aspirin therapy (75 to $162 \mathrm{mg}$ ) in intermediate-risk women as long as blood pressure is controlled and benefit is likely to outweigh risk of gastrointestinal side effects. (Class Ila, Level B) $)_{\mathrm{Gl}=2}$

\section{$\beta$-Blockers}

$\beta$-Blockers should be used indefinitely in all women who have had a myocardial infarction or who have chronic ischemic syndromes unless contraindicated. (Class I, Level $A)_{\mathrm{Gl}=1}$

\section{ACE inhibitors}

ACE inhibitors should be used (unless contraindicated) in high-risk* women. (Class I, Level $A)_{\mathrm{Gl}=1}$

\section{ARBs}

ARBs should be used in high-risk* women with clinical evidence of heart failure or an ejection fraction $<40 \%$ who are intolerant to ACE inhibitors. (Class I, Level B) Gl $=1_{1}$

\section{Atrial fibrillation/stroke prevention}

\section{Warfarin-atrial fibrillation}

Among women with chronic or paroxysmal atrial fibrillation, warfarin should be used to maintain the INR at 2.0 to 3.0 unless they are considered to be at low risk for stroke $(<1 \% / y)$ or high risk of bleeding. (Class I, Level $A)_{\mathrm{Gl}}=1$

\section{Aspirin-atrial fibrillation}

Aspirin $(325 \mathrm{mg}$ ) should be used in women with chronic or paroxysmal atrial fibrillation with a contraindication to warfarin or at low risk for stroke $(<1 \% / \mathrm{y})$. (Class I, Level $\mathrm{A})_{\mathrm{Gl}=1}$

\section{Class III interventions}

\section{Hormone therapy}

Combined estrogen plus progestin hormone therapy should not be initiated to prevent CVD in postmenopausal women. (Class III, Level A)

Combined estrogen plus progestin hormone therapy should not be continued to prevent CVD in postmenopausal women.

(Class III, Level C)

Other forms of menopausal hormone therapy (eg, unopposed estrogen) should not be initiated or continued to prevent CVD in postmenopausal women pending the results of ongoing trials. (Class III, Level C)

\section{Antioxidant supplements}

Antioxidant vitamin supplements should not be used to prevent CVD pending the results of ongoing trials. (Class III, Level A) $)_{\mathrm{Gl}=1}$

\section{Aspirin-lower riskł}

Routine use of aspirin in lower-risk women is not recommended pending the results of ongoing trials. (Class III, Level $\mathrm{B})_{\mathrm{Gl}=2}$

Gl indicates generalizability index; LDL-C, low-density lipoprotein cholesterol; HDL-C, high-density lipoprotein cholesterol; ACE, angiotensin-converting enzyme; and ARB, angiotensin receptor blocker.

*High risk is defined as CHD or risk equivalent, or 10 -year absolute $\mathrm{CHD}$ risk $>20 \%$.

†Intermediate risk is defined as 10 -year absolute CHD risk $10 \%$ to $20 \%$.

łLower risk is defined as 10-year absolute CHD risk $<10 \%$.

$\S$ Dietary supplement niacin must not be used as a substitute for prescription niacin, and over-the-counter niacin should only be used if approved and monitored by a physician. 
TABLE 5. Internet Resources With Supporting Materials for Selected Recommendations

\begin{tabular}{|c|c|c|}
\hline Clinical Recommendation & Recommended Web Site & Comments \\
\hline Cigarette smoking & $\begin{array}{l}\text { http://www.surgeongeneral.gov/tobacco/ } \\
\text { treating_tobacco_use.pdf }\end{array}$ & Treating Tobacco Use and Dependence \\
\hline Diet & http://www.cfsan.fda.gov/ frf/sea-mehg.html & Mercury Levels in Seafood Species \\
\hline Weight management & http://www.nhlbi.nih.gov/guidelines/obesity/ob_home.htm & $\begin{array}{l}\text { Clinical Guidelines on the Identification, Evaluation, and } \\
\text { Treatment of Overweight and Obesity in Adults }\end{array}$ \\
\hline Lipids & http://circ.ahajournals.org/cgi/reprint/106/25/3143.pdf & $\begin{array}{l}\text { Third Report of the National Cholesterol Education Program } \\
\text { Adult Treatment Panel III (NCEP ATP III) }\end{array}$ \\
\hline \multirow[t]{2}{*}{ Blood pressure } & http://hyper.ahajournals.org/cgi/content/full/42/6/1206 & $\begin{array}{l}\text { Seventh Report of the Joint National Committee on } \\
\text { Prevention, Detection, Evaluation, and Treatment of High } \\
\text { Blood Pressure (JNC 7) }\end{array}$ \\
\hline & $\begin{array}{l}\text { http://www.nhlbi.nih.gov/health/public/heart/hbp/dash/ } \\
\text { index.htm }\end{array}$ & $\begin{array}{l}\text { Dietary Approaches to Stop Hypertension (DASH) Eating } \\
\text { Plan }\end{array}$ \\
\hline \multirow[t]{2}{*}{ Diabetes } & http://www.diabetes.org/home.jsp & American Diabetes Association \\
\hline & http://circ.ahajournals.org/cgi/content/full/105/18/2231 & $\begin{array}{l}\text { AHA Conference Proceedings: Prevention Conference VI: } \\
\text { Diabetes and Cardiovascular Disease }\end{array}$ \\
\hline \multirow[t]{2}{*}{ Atrial fibrillation/stroke prevention } & http://www.nhlbi.nih.gov/about/framingham/stroke.htm & Framingham Stroke Risk Scoring System \\
\hline & $\begin{array}{l}\text { http://www.americanheart.org/downloadable/heart/ } \\
\text { 222_ja20017993p_1.pdf }\end{array}$ & $\begin{array}{l}\text { ACC/AHA/ESC Guidelines for the Management of Patients } \\
\text { With Atrial Fibrillation }\end{array}$ \\
\hline Absolute CHD risk calculation & http://www.nhlbi.nih.gov/guidelines/cholesterol/index.htm & Framingham CHD Risk Scoring System \\
\hline
\end{tabular}

All sites were accessed on and available as of December 16, 2003.

Our dietary recommendations emphasize intake of a variety of heart-healthy foods. The panel concluded that intake of fish has been associated with a reduced risk of CVD. The benefits of fish seem to result, at least in part, from omega-3 fatty acids. Nonetheless, women of childbearing age, especially pregnant women, should avoid shark, swordfish, king mackerel, and tilefish because the relatively high content of mercury in these fish may impair fetal neurological development. Still, these women can eat other kinds of fish, such as catfish, flounder, and salmon, which have less mercury. For a more complete listing of mercury levels in different types of fish, see the US Food and Drug Administration web site at http://www.cfsan.fda.gov/ frf/ sea-mehg.html (Table 5). Women who do not eat fish might consider nonmarine sources of omega-3 fatty acids, such as flaxseed oil, walnut oil, canola oil, soybean oil, or walnuts. However, there is less evidence supporting a cardiovascular benefit from these sources of omega-3 fatty acids. ${ }^{14}$

\section{TABLE 6. CVD Prevention Strategies for Clinical Practice}

1. Assess and stratify women into high, intermediate, lower, or optimal risk categories.

2. Lifestyle approaches (smoking cessation, regular exercise, weight management, and heart-healthy diet) to prevent CVD are Class I recommendations for all women and a top priority in clinical practice.

3. Other CVD risk-reducing interventions should be prioritized on the basis of strength of recommendation (Class I > Class Ila $>$ Class Ilb) and within each class of recommendation on the basis of the level of evidence, with the exception of lifestyle, which is a top priority for all women $(A>B>C)$.

4. Highest priority for risk intervention in clinical practice is based on risk stratification: (high risk $>$ intermediate risk $>$ lower risk $>$ optimal risk).

5. Avoid interventions designated as Class III.
Other expert panels and organizations (including the National Cholesterol Education Program Adult Treatment Panel III [NCEP ATP III]; the Seventh Report of the Joint National Committee on Prevention, Detection, Evaluation, and Treatment of High Blood Pressure [JNC 7], and the American Diabetes Association) have addressed control of major risk factors extensively and can be referred to for more specific information about management approaches (Table 5).9,15,16 For example, our recommendation to encourage an optimal blood pressure through lifestyle approaches should be implemented using more detailed information from the JNC 7 report about weight management, adopting a DASH (Dietary Approaches to Stop Hypertension) eating plan, dietary sodium reduction, physical activity, and moderation of alcohol consumption. ${ }^{15}$ Similarly, NCEP ATP III provides algorithms for cholesterol management and is updated as new evidence becomes available. ${ }^{9}$ According to NCEP/ATP III, LDL cholesterol is the primary target of lipid-lowering therapy, and intensity of therapy should be matched to the absolute risk of the patient. Glycemic control received a Class I recommendation from the Expert Panel. Treatment of hyperglycemia has been shown to reduce or delay complications of diabetes such as retinopathy, nephropathy, and neuropathy, which underscores the importance of glycemic control in diabetic patients. ${ }^{16}$ Moreover, both lifestyle intervention and (to a lesser degree) metformin therapy have been shown to reduce the incidence of diabetes. ${ }^{17}$

Although there was good consensus on the use of aspirin ( 75 to $162 \mathrm{mg}$ ) in high-risk women, recommendations for aspirin therapy in intermediate- and lower-risk women were more challenging. The difficulty in developing these recommendations was due to the lack of data from primary prevention trials that included women and the possibility that data on men may not necessarily be extrapolated to women. 


\section{TABLE 7. Priorities for Prevention in Practice According to Risk Group}

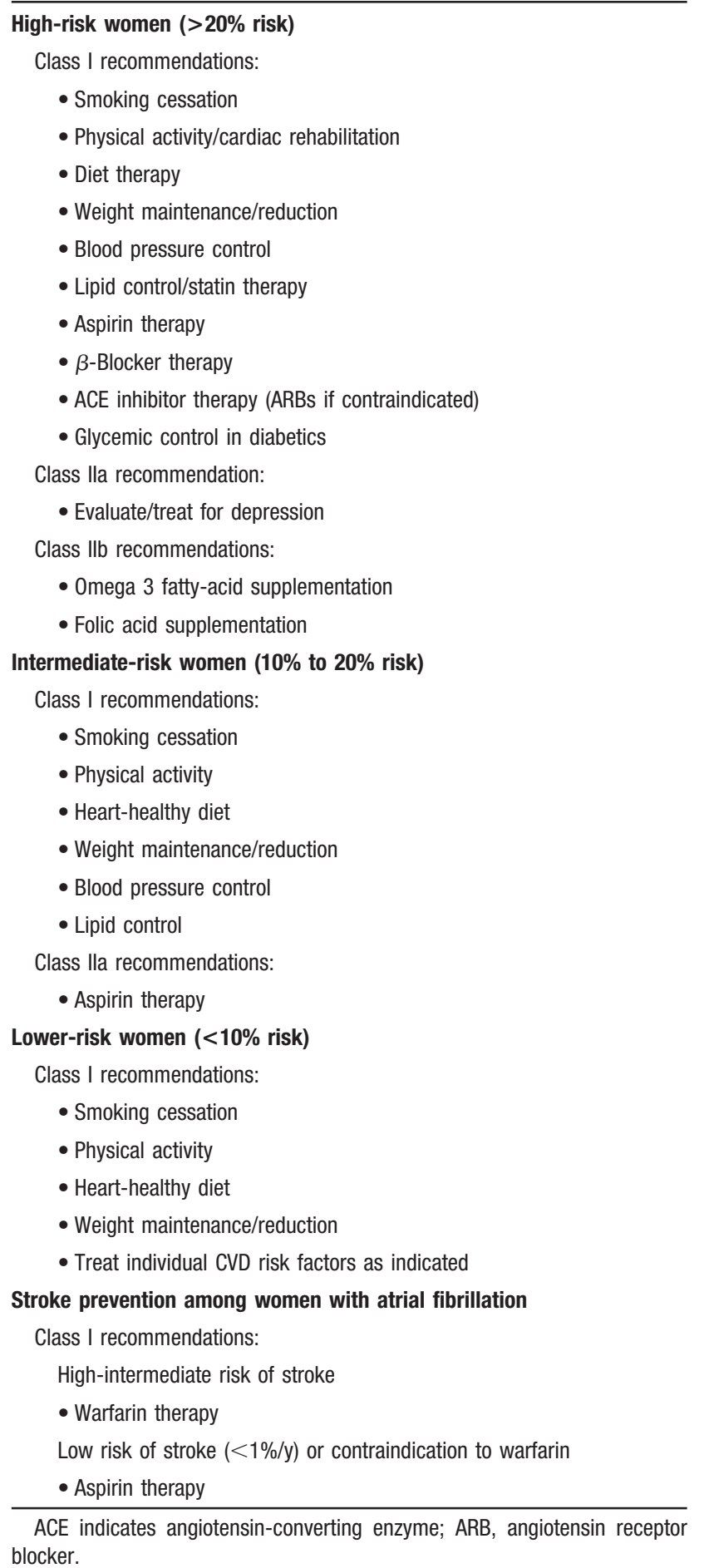

Uncontrolled hypertension is not uncommon in women, and aspirin therapy may increase the risk of hemorrhagic stroke in this setting. Moreover, the risk of gastrointestinal bleeding and other side effects may outweigh the potential benefits of aspirin in women at lower risk for CVD. The panel suggested a conservative approach, pending the results of ongoing clinical trials. It was also noted that nonsteroidal antiinflammatory medications should not be substituted for aspirin for CVD prevention. For stroke prevention among women with atrial fibrillation, a dose of $325 \mathrm{mg}$ of aspirin is needed if there is a contraindication to warfarin therapy or if the risk of a stroke is considered low ( $<1 \%$ annual event rate per year). Tools to determine stroke risk are available at http://www.nhlbi. nih.gov/about/framingham/stroke.htm (Table 5).

The Class III recommendations on hormone therapy and antioxidant supplementation were based on recent clinical trials showing no benefit for CVD prevention and possible adverse effects of these interventions. The panel acknowledged that major trials have been limited to specific types and dosages of these agents, and those results may not generalize to compounds not tested in clinical studies. In particular, ongoing trials will give more information about unopposed estrogen therapy and clinical outcomes. However, given the unproven benefit and possible harm associated with postmenopausal hormone therapies, it was suggested that a conservative approach be taken in clinical practice unless further research is available to support use for CVD prevention. The use of hormone therapy for menopausal symptoms has been addressed by other professional societies. ${ }^{18,19} \mathrm{Al}$ though hormone therapy is not recommended for CVD prevention, women and their healthcare providers should weigh the potential risks of therapy against the potential benefits for menopausal symptom control.

\section{Limitations}

The process of developing clinical guidelines has several limitations, even when a systematic approach is undertaken. Most importantly, data used to establish recommendations might be generated from populations that do not reflect the characteristics of the patient being treated, and individual responses can vary significantly. The clinical cardiovascular end points chosen for inclusion in the systematic evaluation do not necessarily reflect the net clinical impact and do not include many end points that are clinically important but often not reported (eg, symptoms, quality of life, functional status, hospitalizations, resource utilization, etc). We simplified the recommendation for each level of risk for purposes of clinical utility and acknowledge that there might be variability in efficacy and effectiveness of various interventions within the same risk intervention category (eg, various doses or types of physical activity or drugs within the same class may yield different results). The Framingham risk score may not apply equally to all populations, but it performs well within subgroups. ${ }^{20,21} \mathrm{We}$ may have omitted or included some studies because of the limitations of electronic searching and human error; however, the likelihood that such an inadvertent omission or inclusion would alter a recommendation is small. Our recommendations are based on evidence available to the panel through November 2003, and as science evolves, recommendations may have to be revised. Finally, we do not include a comprehensive plan for implementation of the guidelines in this document. The AHA is developing professional education programs and other initiatives to facilitate the dissemination and implementation of the guidelines.

\section{Conclusions and Future Directions}

Overwhelming evidence suggests that CVD can be prevented in both women and men. Clinical recommendations are provided to assist healthcare providers and the public in 
efforts to avoid an initial or recurrent cardiovascular event. Strategies to implement these guidelines and prioritize riskreducing therapies in clinical practice are outlined in Tables 6 and 7. Our systematic search of the literature shows that several prevention strategies are likely to have substantially greater benefit than risk and that some interventions are likely to be associated with greater risk than benefit. It is important that the public be appropriately informed about potentially lifesaving preventive therapies and take action to lower their risk. On the basis of our review of the scientific evidence, it appears the risk of no action is far greater than that of applying knowledge to prevent CVD. Approximately $75 \%$ of the original research articles that met our inclusion criteria included female subjects, and very few presented race/ethnicspecific analyses. Moreover, few studies included elderly women, especially those over 80, in whom CVD is common. The results of this project highlight the need to include diverse populations in research studies and to present subgroup analyses so that guidance can be tailored, if appropriate, to subpopulations. These recommendations are meant to assist clinicians on the basis of our current state of evidence and supersede previous AHA prevention guidelines with regard to women. ${ }^{1,10,11,22}$ Because health care is a blend of science and art, we emphasize that guidelines are not a substitute for good clinical judgment.

\section{Acknowledgments}

We are grateful to the Foundation for the Advancement of Cardiac Therapies (FACT) Foundation, Palm Beach, Fla, for providing financial support for the literature searches and to the Duke Center for Clinical Health Policy Research, Durham, NC, for conducting and summarizing the systematic searches. Persons from Duke who contributed to this project include Rowena J. Dolor, MD, MHS; L. Kristin Newby, MD, MHS; Lori A. Bastian, MD, MPH; Mike Blazing, MD; Ann J. Brown, MD, FACE; Tracy W. Gaudet, MD; Richard S. Liebowitz, MD; Kenneth W. Mahaffey, MD; Alison A. Lee, MA, MPH; Rebecca Gray, DPhil; Ayn C. Huntington, BA; Allison Meyer; Mimi Sengupta Biswas, MD, MHSc; Daniel R. Bensimhon, MD; Adi Cohen, MD; Suneet Kaur, MD; Abhi Goyal, MD; Svati H. Shah, MD; John L. Petersen, MD; Jonathan E.E. Yager, MD; Jean-Pierre Dery, MD, $\operatorname{FRCP}(C)$; and Camille G. Frazier, MD. The assistance of Lisa Rehm in coordinating this manuscript is greatly appreciated.

\section{References}

1. Mosca L, Grundy SM, Judelson D, et al. Guide to preventive cardiology for women. AHA/ACC scientific statement, consensus panel statement. Circulation. 1999;99:2480-2484.

2. American Heart Association. Heart disease and stroke statistics-2003 update. Dallas, Tex: American Heart Association; 2002.

3. Yusuf S, Reddy S, Ounpuu S, et al. Global burden of cardiovascular diseases: part I: general considerations, the epidemiologic transition, risk factors, and impact of urbanization. Circulation. 2001;104:2746-2753.

4. Rossouw JE, Anderson GL, Prentice RL, et al. Risks and benefits of estrogen plus progestin in healthy postmenopausal women: principal results from the Women's Health Initiative randomized controlled trial. Writing group for the Women's Health Initiative investigators. JAMA. 2002;288:321-333.
Summary for patients in: CMAJ. 2002;167:377-378, and J Fam Pract. 2002;51:821.

5. Manson JE, Hsia J, Johnson KC, et al. Estrogen plus progestin and the risk of coronary heart disease. Women's Health Initiative investigators. $N$ Engl J Med. 2003;349:523-534.

6. Wassertheil-Smoller S, Hendrix SL, Limacher M, et al. Effect of estrogen plus progestin on stroke in postmenopausal women: the Women's Health Initiative: a randomized trial. Women's Health Initiative investigators. JAMA. 2003;289:2673-2684.

7. Hulley S, Grady D, Bush T, et al. Randomized trial of estrogen plus progestin for secondary prevention of coronary heart disease in postmenopausal women. Heart and Estrogen/Progestin Replacement Study (HERS) research group. JAMA. 1998;280:605-613.

8. Meinert CL, Gilpin AK, Unalp A, et al. Gender representation in trials. Control Clin Trials. 2000;21:462-475.

9. Executive summary of the Third Report of the National Cholesterol Education Program (NCEP) expert panel on detection, evaluation, and treatment of high blood cholesterol in adults (Adult Treatment Panel III). JAMA. 2001;285:2486-2497.

10. Smith S, Blair S, Bonow R, et al. AHA/ACC scientific statement: AHA/ACC guidelines for preventing heart attack and death in patients with atherosclerotic cardiovascular disease: 2001 update: a statement for healthcare professionals from the American Heart Association and the American College of Cardiology. Circulation. 2001;104:1577-1579.

11. Pearson TA, Blair SN, Daniels SR, et al. AHA guidelines for primary prevention of cardiovascular disease and stroke: 2002 update: consensus panel guide to comprehensive risk reduction for adult patients without coronary or other atherosclerotic vascular diseases. American Heart Association Science Advisory and Coordinating Committee. Circulation. 2002;106: 388-391.

12. Gibbons R, Smith S, Antman E. American College of Cardiology/American Heart Association Clinical Practice Guidelines: Part I: where do they come from? Circulation. 2003;107:2979-2986.

13. Benjamin EJ, Smith SC, Cooper RS, et al. Task Force \#1-magnitude of the prevention problem: opportunities and challenges. 33rd Bethesda Conference. J Am Coll Cardiol. 2002;40:588-603.

14. Kris-Etherton PM, Harris WS, Appel LJ. Fish consumption, fish oil, omega-3 fatty acids, and cardiovascular disease. Scientific statement of the American Heart Association Nutrition Committee. Circulation. 2002;106:2747-2757. Erratum in: Circulation. 2003;107:512.

15. Chobanian AV, Bakris GL, Black HR, et al. The Seventh Report of the Joint National Committee on Prevention, Detection, Evaluation, and Treatment of High Blood Pressure: the JNC 7 report. JAMA. 2003;289:2560-2572. Erratum in: JAMA. 2003;290:197.

16. American Diabetes Association. Implications of the diabetes control and complications trial. Diabetes Care. 2003;26(suppl 1):S25-S27.

17. Knowler WC, Barrett-Connor E, Fowler SE, et al. Reduction in the incidence of type II diabetes with lifestyle intervention or metformin. $N$ Engl J Med. 2002;346:393-403.

18. American College of Obstetricians and Gynecologists. Response to Women's Health Initative Study Results by the American College of Obstetricians and Gynecologists. June 3, 2003. Available at http://www.acog.com/member_access/misc/whiResponse.cfm.

19. The North American Menopause Society. Estrogen and progestogen use in peri- and postmenopausal women: September 2003 position statement of The North American Menopause Society. Menopause. 2003;10:497-506.

20. D'Agostino RB Sr, Grundy S, Sullivan LM, et al. Validation of the Framingham coronary heart disease prediction scores: results of a multiple ethnic groups investigation. CHD Risk Prediction Group. JAMA. 2001;286:180-187.

21. Grundy SM, D’Agostino Sr RB, Mosca L. Cardiovascular risk assessment based on US cohort studies: findings from a National Heart, Lung, and Blood institute workshop. Circulation. 2001;104:491-496.

22. Mosca L, Collins P, Herrington DM, et al. Hormone replacement therapy and cardiovascular disease: a statement for healthcare professionals from the American Heart Association. Circulation. 2001;104:499-503. 


\section{Appendix I}

\section{Framingham Point Score Estimate of 10-Year Risk for Women}

\begin{tabular}{ll} 
Age & Points \\
\hline $20-34$ & -7 \\
$35-39$ & -3 \\
$40-44$ & 0 \\
$45-49$ & 3 \\
$50-54$ & 6 \\
$55-59$ & 8 \\
$60-64$ & 10 \\
$65-69$ & 12 \\
$70-74$ & 14 \\
$75-79$ & 16
\end{tabular}

\begin{tabular}{lcccccc}
\multicolumn{7}{c}{ Points } \\
\cline { 2 - 6 } \multicolumn{1}{c}{ Total Cholesterol (mg/d)) } & Age 20-39 & Age & 40-49 & Age 50-59 & Age 60-69 & Age 70-7 99 \\
\hline$<160$ & 0 & 0 & 0 & 0 & 0 \\
$160-199$ & 4 & 3 & 2 & 1 & 1 \\
$200-239$ & 8 & 6 & 4 & 2 & 1 \\
$240-279$ & 11 & 8 & 5 & 3 & 2 \\
$\geq 280$ & 13 & 10 & 7 & 4 & 2
\end{tabular}

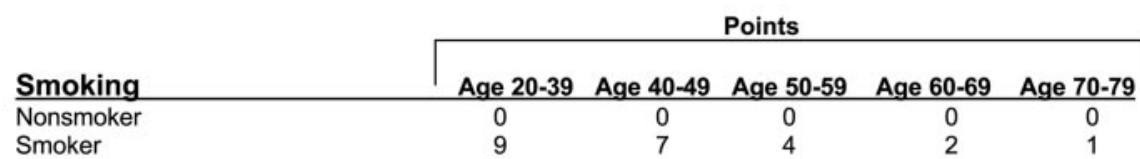

\begin{tabular}{lc} 
HDL $(\mathrm{mg} / \mathrm{d}$ ) $)$ & Points \\
\hline$\geq 60$ & -1 \\
$50-59$ & 0 \\
$40-49$ & 1 \\
$<40$ & 2
\end{tabular}

\begin{tabular}{lcc} 
Systolic $\mathbf{B P}(\mathbf{m m H g})$ & If Untreated & If Treated \\
\hline$<120$ & 0 & 0 \\
$120-129$ & 1 & 3 \\
$130-139$ & 2 & 4 \\
$140-159$ & 3 & 5 \\
$\geq 160$ & 4 & 6
\end{tabular}

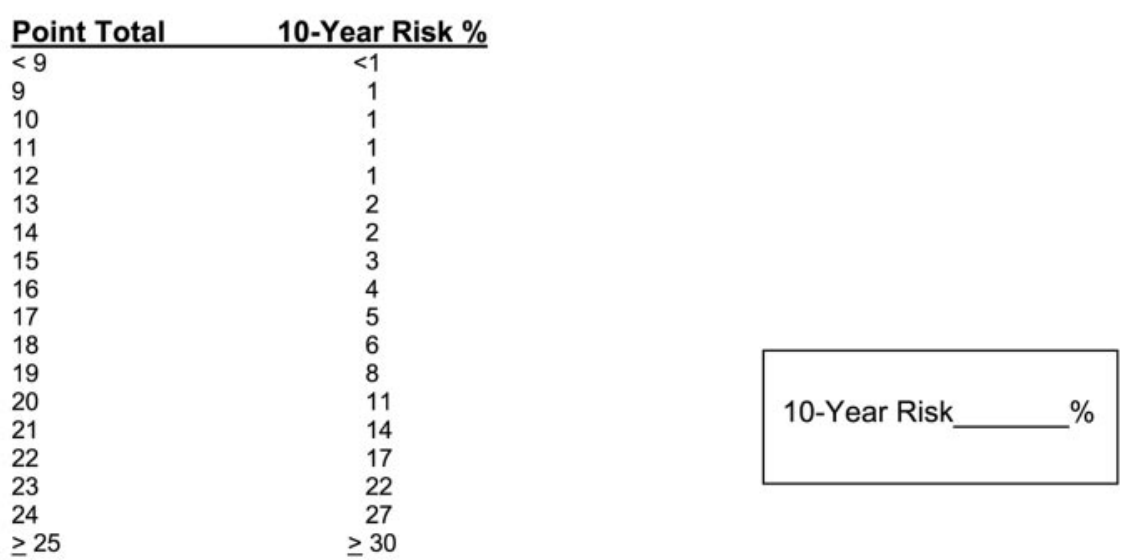

A more precise method of calculating CHD risk in women is available online at http://www.nhlbi.nih.gov/guidelines/cholesterol/index.htm. Adapted from the Third Report of the National Cholesterol Education Program (NCEP) Expert Panel on Detection Evaluation, and Treatment of High Blood Cholesterol in Adults (Adult Treatment Panel III): Final Report (Circulation. 2002;106:3143-3421), Table III. 1-6, p 3231. 


\section{Appendix II}

Original research articles identified through systematic search by topic (summary evidence tables on web).

\section{Hyperlipidemia}

1. Major outcomes in moderately hypercholesterolemic, hypertensive patients randomized-pravastatin versus usual care: The Antihypertensive and Lipid-Lowering treatment to prevent Heart Attack Trial (ALLHAT-LLT). ALLHAT Officers and Coordinators for the ALLHAT collaborative research group. JAMA. 2002;288:2998-3007.

2. Aronow WS, Ahn C. Incidence of new coronary events in older persons with prior myocardial infarction and serum low-density lipoprotein cholesterol $>$ or $=125 \mathrm{mg} / \mathrm{dL}$ treated with statins versus no lipid-lowering drug. Am J Cardiol. 2002;89:67-69.

3. Aronow WS, Ahn C. Frequency of new coronary events in older persons with peripheral arterial disease and serum low-density lipoprotein cholesterol $>$ or $=125 \mathrm{mg} / \mathrm{dL}$ treated with statins versus no lipid-lowering drug. Am J Cardiol. 2002;90:789-791.

4. Athyros VG, Papageorgiou AA, Mercouris BR, et al. Treatment with atorvastatin: the National Cholesterol Educational Program goal versus 'usual' care in secondary coronary heart disease prevention. The GREek Atorvastatin and Coronary-heart-disease Evaluation (GREACE) study. Curr Med Res Opin. 2002;18:220-228.

5. Brown BG, Zhao XQ, Chait A, et al. Simvastatin and niacin, antioxidant vitamins, or the combination for the prevention of coronary disease. N Engl J Med. 2001;345:1583-1592.

6. Buchwald H, Varco RL, Matts JP, et al. Effect of partial ileal bypass surgery on mortality and morbidity from coronary heart disease in patients with hypercholesterolemia: report of the Program on the Surgical Control of the Hyperlipidemias (POSCH). $N$ Engl $J$ Med. 1990;323:946-955.

7. Burr ML, Fehily AM, Gilbert JF, et al. Effects of changes in fat, fish, and fiber intakes on death and myocardial reinfarction: diet and reinfarction trial (DART). Lancet. 1989;2:757-761.

8. Chan AW, Bhatt DL, Chew DP, et al. Early and sustained survival benefit associated with statin therapy at the time of percutaneous coronary intervention. Circulation. 2002;105:691-696.

9. Colivicchi F, Guido V, Tubaro M, et al. Effects of atorvastatin $80 \mathrm{mg}$ daily early after onset of unstable angina pectoris or non-Q-wave myocardial infarction. Am J Cardiol. 2002;90:872-874.

10. A co-operative trial in the primary prevention of ischemic heart disease using clofibrate: report from the Committee of Principal Investigators. $\mathrm{Br}$ Heart J. 1978;40:1069-1118.

11. Clofibrate and niacin in coronary heart disease: Coronary Drug Project research group. JAMA. 1975;231:360-381.

12. Dorr AE, Gundersen K, Schneider JC, et al. Colestipol hydrochloride in hypercholesterolemic patients: effect on serum cholesterol and mortality. J Chronic Dis. 1978;31:5-14.

13. Downs JR, Clearfield M, Weis S, et al. Primary prevention of acute coronary events with lovastatin in men and women with average cholesterol levels: results of AFCAPS/TexCAPS. Air Force/Texas Coronary Atherosclerosis Prevention Study. JAMA. 1998;279:1615-1622.

14. Frantz ID, Dawson EA, Ashman PL, et al. Test of effect of lipid lowering by diet on cardiovascular risk: the Minnesota Coronary Survey. Arteriosclerosis 1989;9:129-135.

15. Frick MH, Elo O, Haapa K, et al. Helsinki Heart Study: primaryprevention trial with gemfibrozil in middle-aged men with dyslipidemia: safety of treatment, changes in risk factors, and incidence of coronary heart disease. N Engl J Med. 1987;317:1237-1245.

16. Frick MH, Heinonen OP, Huttunen JK, et al. Efficacy of gemfibrozil in dyslipidaemic subjects with suspected heart disease: an ancillary study in the Helsinki Heart Study frame population. Ann Med. 1993;25:41-5.

17. Furberg CD, Adams HP, Applegate WB, et al. Effect of lovastatin on early carotid atherosclerosis and cardiovascular events: Asymptomatic Carotid Artery Progression Study (ACAPS) Research Group. Circulation. 1994;90:1679-1687.

18. MRC/BHF Heart Protection Study of cholesterol lowering with simvastatin in 20,536 high-risk individuals: a randomized placebo-controlled trial. Heart Protection Study collaborative group. Lancet. 2002;360:7-22.

19. Isles CG, Hole DJ, Hawthorne VM, et al. Relation between coronary risk and coronary mortality in women of the Renfrew and Paisley survey: comparison with men. Lancet. 1992;339:702-706.
20. Lemaitre RN, Psaty BM, Heckbert SR, et al. Therapy with hydroxymethylglutaryl coenzyme a reductase inhibitors (statins) and associated risk of incident cardiovascular events in older adults: evidence from the Cardiovascular Health Study. Arch Intern Med. 2002;162:1395-1400.

21. Reduction in incidence of coronary heart disease: the Lipid Research Clinics Coronary Primary Prevention Trial results. JAMA. 1984;251:351-364.

22. Prevention of cardiovascular events and death with pravastatin in patients with coronary heart disease and a broad range of initial cholesterol levels: the Long-Term Intervention with Pravastatin in Ischemic Disease (LIPID) study group. N Engl J Med. 1998;339:1349-1357.

23. Meade T, Zuhrie R, Cook C, et al. Bezafibrate in men with lower extremity arterial disease: randomized controlled trial. BMJ. 2002;325:1139.

24. Trial of clofibrate in the treatment of ischemic heart disease: five-year study by a group of physicians of the region. Newcastle on Tyne Physicians. BMJ. 1971;4:767-775.

25. Pitt B, Waters D, Brown WV, et al. Aggressive lipid-lowering therapy compared with angioplasty in stable coronary artery disease: Atorvastatin versus Revascularization Treatment Investigators. $N$ Engl $\mathrm{J}$ Med. 1999;341:70-76.

26. The effect of aggressive lowering of low-density lipoprotein cholesterol levels and low-dose anticoagulation on obstructive changes in saphenous-vein coronary-artery bypass grafts: the Post Coronary Artery Bypass Graft trial investigators. N Engl J Med. 1997;336:153-162.

27. Effects of pravastatin in patients with serum total cholesterol levels from $5.2-7.8 \mathrm{mmol} /(200-300 \mathrm{mg} / \mathrm{dL})$ plus two additional atherosclerotic risk factors: the Pravastatin Multinational Study Group for Cardiac Risk Patients. Am J Cardiol. 1993;72:1031-1037.

28. Low-fat diet in myocardial infarction: a controlled trial. Lancet. 1965;2:501-504

29. Rosenhamer G, Carlson LA. Effect of combined clofibrate-nicotinic acid treatment in ischemic heart disease. Atherosclerosis. 1980;37:129-142.

30. Rubins HB, Robins SJ, Collins D, et al. Gemfibrozil for the secondary prevention of coronary heart disease in men with low levels of highdensity lipoprotein cholesterol: Veterans Affairs High-Density Lipoprotein Cholesterol Intervention Trial study group. $N$ Engl J Med. 1999;341:410-418.

31. Sacks FM, Pfeffer MA, Moye LA, et al. The effect of pravastatin on coronary events after myocardial infarction in patients with average cholesterol levels: Cholesterol and Recurrent Events Trial investigators. N Engl J Med. 1996;335:1001-1009.

32. Randomized trial of cholesterol lowering in 4444 patients with coronary heart disease: the Scandinavian Simvastatin Survival Study (4S). Lancet. 1994;344:1383-1389.

33. Ischemic heart disease: a secondary prevention trial using clofibrate: report by a research committee of the Scottish Society of Physicians. BMJ. 1971;4:775-784.

34. Schwartz GG, Olsson AG, Ezekowitz MD, et al. Effects of atorvastatin on early recurrent ischemic events in acute coronary syndromes: the MIRACL study: a randomized controlled trial. JAMA. 2001;285:1711-1718.

35. Serruys PW, de Feyter P, Macaya C, et al. Fluvastatin for prevention of cardiac events following successful first percutaneous coronary intervention: a randomized controlled trial. JAMA. 2002;287:3215-3222.

36. Sever PS, Dahlof B, Poulter NR, et al. Prevention of coronary and stroke events with atorvastatin in hypertensive patients who have average or lower-than-average cholesterol concentrations, in the AngloScandinavian Cardiac Outcomes Trial-Lipid Lowering Arm (ASCOT-LLA): a multicenter randomized controlled trial. Lancet. 2003;361:1149-1158

37. Shepherd J, Blauw GJ, Murphy MB, et al. Pravastatin in elderly individuals at risk of vascular disease (PROSPER): a randomized controlled trial. Lancet. 2002;360:1623-1630.

38. Shepherd J, Cobbe SM, Ford I, et al. Prevention of coronary heart disease with pravastatin in men with hypercholesterolemia: West of Scotland Coronary Prevention study group. N Engl J Med. 1995;333:1301-1307.

39. Stenestrand U, Wallentin L. Early statin treatment following acute myocardial infarction and 1-year survival: Swedish Register of Cardiac Intensive Care (RIKS-HIA). JAMA. 2001;285:430-436.

40. Woodhill JM, Palmer AJ, Leelarthaepin B, et al. Low fat, low cholesterol diet in secondary prevention of coronary heart disease. Adv Exp Med Biol. 1978;109:317-330. 


\section{Meta-Analyses}

1. Aronow WS, Ahn C. Frequency of new coronary events in older persons with peripheral arterial disease and serum low-density lipoprotein cholesterol $>$ or $=125 \mathrm{mg} / \mathrm{dL}$ treated with statins versus no lipid-lowering drug. Am J Cardiol. 2002;90:789-791.

2. Bucher HC, Griffith LE, Guyatt GH. Effect of HMGcoA reductase inhibitors on stroke: a meta-analysis of randomized, controlled trials. Ann Intern Med. 1998;128:89-95.

3. Buchwald H, Campos CT, Boen JR, et al. Gender-based mortality follow-up from the Program on the Surgical Control of the Hyperlipidemias (POSCH) and meta-analysis of lipid intervention trials: women in POSCH and other lipid trials. Ann Surg. 1996;224:486-498; discussion 498-500.

4. Corvol JC, Bouzamondo A, Sirol M, et al. Differential effects of lipidlowering therapies on stroke prevention: a meta-analysis of randomized trials. Arch Intern Med. 2003;163:669-676.

5. Marchioli R, Marfisi RM, Carinci F, et al. Meta-analysis, clinical trials, and transferability of research results into practice: the case of cholesterol-lowering interventions in the secondary prevention of coronary heart disease. Arch Intern Med. 1996;156:1158-1172.

\section{Physical Activity}

1. Albert CM, Mittleman MA, Chae CU, et al. Triggering of sudden death from cardiac causes by vigorous exertion. $N$ Engl J Med. 2000;343:1355-1361.

2. Batty GD, Shipley MJ, Marmot MG, et al. Leisure time physical activity and disease-specific mortality among men with chronic bronchitis: evidence from the Whitehall study. Am J Public Health. 2003;93:817-821.

3. Costas P Jr, Garcia-Palmieri MR, Nazario E, et al. Relation of lipids, weight, and physical activity to incidence of coronary heart disease: the Puerto Rico heart study. Am J Cardiol. 1978;42:653-658.

4. D'Avanzo B, Santoro L, La Vecchia C, et al. Physical activity and the risk of acute myocardial infarction. GISSI-EFRIM Investigators: Gruppo Italiano per lo Studio della Sopravvivenza nell'Infarto-Epidemiologia dei Fattori di Rischio dell'Infarto Miocardico. Ann Epidemiol. 1993;3:645-651.

5. Donahue RP, Abbott RD, Reed DM, et al. Physical activity and coronary heart disease in middle-aged and elderly men: the Honolulu Heart Program. Am J Public Health. 1988;78:683-685.

6. Dorn JP, Cerny FJ, Epstein LH, et al. Work and leisure time physical activity and mortality in men and women from a general population sample. Ann Epidemiol. 1999;9:366-373.

7. Eaton CB, Medalie JH, Flocke SA, et al. Self-reported physical activity predicts long-term coronary heart disease and all-cause mortalities: twenty-one-year follow-up of the Israeli Ischemic Heart Disease Study. Arch Fam Med. 1995;4:323-329.

8. Folsom AR, Arnett DK, Hutchinson RG, et al. Physical activity and incidence of coronary heart disease in middle-aged women and men. Med Sci Sports Exerc. 1997;29:901-909.

9. Fraser GE, Strahan TM, Sabate J, et al. Effects of traditional coronary risk factors on rates of incident coronary events in a low-risk population: the Adventist Health Study. Circulation. 1992;86:406-413.

10. Gartside PS, Glueck CJ. The important role of modifiable dietary and behavioral characteristics in the causation and prevention of coronary heart disease hospitalization and mortality: the prospective NHANES I follow-up study. J Am Coll Nutr. 1995;14:71-79.

11. Gartside PS, Wang P, Glueck CJ. Prospective assessment of coronary heart disease risk factors: the NHANES I epidemiologic follow-up study (NHEFS) 16-year follow-up. J Am Coll Nutr. 1998;17:263-269.

12. Gyntelberg F, Lauridsen L, Schubell K. Physical fitness and risk of myocardial infarction in Copenhagen males aged 40-59: a five- and seven-year follow-up study. Scand J Work Environ Health. 1980;6:170-178.

13. Haapanen N, Miilunpalo S, Vuori I, et al. Association of leisure time physical activity with the risk of coronary heart disease, hypertension and diabetes in middle-aged men and women. Int $J$ Epidemiol. 1997;26:739-747.

14. Haapanen-Niemi N, Miilunpalo S, Pasanen M, et al. Body mass index, physical inactivity and low level of physical fitness as determinants of all-cause and cardiovascular disease mortality: 16 years follow-up of middle-aged and elderly men and women. Int J Obes Relat Metab Disord. 2000;24:1465-1474.
15. He J, Ogden LG, Bazzano LA, et al. Risk factors for congestive heart failure in US men and women: NHANES I epidemiologic follow-up study. Arch Intern Med. 2001;161:996-1002.

16. Hein HO, Suadicani P, Gyntelberg F. Physical fitness or physical activity as a predictor of ischemic heart disease?: a 17-year follow-up in the Copenhagen Male Study. J Intern Med. 1992;232:471-479.

17. Hippe M, Vestbo J, Hein HO, et al. Familial predisposition and susceptibility to the effect of other risk factors for myocardial infarction. $J$ Epidemiol Community Health. 1999;53:269-276.

18. Hu FB, Stampfer MJ, Solomon C, et al. Physical activity and risk for cardiovascular events in diabetic women. Ann Intern Med. 2001;134:96-105.

19. Kaprio J, Kujala UM, Koskenvuo M, et al. Physical activity and other risk factors in male twin-pairs discordant for coronary heart disease. Atherosclerosis. 2000;150:193-200.

20. Kujala UM, Sarna S, Kaprio J, et al. Natural selection: sports, later physical activity habits, and coronary heart disease. Br J Sports Med. 2000;34:445-449.

21. Lakka TA, Venalainen JM, Rauramaa R, et al. Relation of leisure-time physical activity and cardiorespiratory fitness to the risk of acute myocardial infarction. N Engl J Med. 1994;330:1549-1554.

22. Lapidus L, Bengtsson C. Socioeconomic factors and physical activity in relation to cardiovascular disease and death: a 12 year follow up of participants in a population study of women in Gothenburg, Sweden. $\mathrm{Br}$ Heart J. 1986;55:295-301.

23. Lee IM, Rexrode KM, Cook NR, et al. Physical activity and coronary heart disease in women: is "no pain, no gain" passe? JAMA. 2001;285:1447-1454.

24. Leon AS, Connett J, Jacobs DR, et al. Leisure-time physical activity levels and risk of coronary heart disease and death: the Multiple Risk Factor Intervention Trial. JAMA. 1987;258:2388-2395.

25. Leon AS, Connett J. Physical activity and 10.5 year mortality in the Multiple Risk Factor Intervention Trial (MRFIT). Int J Epidemiol. 1991;20:690-697.

26. Leon AS, Myers MJ, Connett J. Leisure time physical activity and the 16-year risks of mortality from coronary heart disease and all-causes in the Multiple Risk Factor Intervention Trial (MRFIT). Int J Sports Med. 1997;18(suppl 3):S208-S215.

27. Manson JE, Hu FB, Rich-Edwards JW, et al. A prospective study of walking as compared with vigorous exercise in the prevention of coronary heart disease in women. N Engl J Med. 1999;341:650-658.

28. Manson JE, Greenland P, LaCroix AZ, et al. Walking compared with vigorous exercise for the prevention of cardiovascular events in women. N Engl J Med. 2002;347:716-725.

29. Martinson BC, O'Connor PJ, Pronk NP. Physical inactivity and short-term all-cause mortality in adults with chronic disease. Arch Intern Med. 2001;161:1173-1180.

30. Morris JN, Clayton DG, Everitt MG, et al. Exercise in leisure time: coronary attack and death rates. Br Heart J. 1990;63:325-334.

31. Mundal R, Erikssen J, Rodahl K. Assessment of physical activity by questionnaire and personal interview with particular reference to fitness and coronary mortality. Eur J Appl Physiol. 1987;56:245-252.

32. Nakayama T, Date C, Yokoyama T, et al. A 15.5-year follow-up study of stroke in a Japanese provincial city: the Shibata Study. Stroke. 1997;28:45-52.

33. Qvist J, Johansson S, Johansson LM. Multivariate analyses of mortality from coronary heart disease due to biological and behavioral factors. Scand J Soc Med. 1996;24:67-76.

34. Rosengren A, Wilhelmsen L. Physical activity protects against coronary death and deaths from all causes in middle-aged men: evidence from a 20-year follow-up of the primary prevention study in Goteborg. Ann Epidemiol. 1997; 7:69-75.

35. Salonen JT, Puska P, Tuomilehto J. Physical activity and risk of myocardial infarction, cerebral stroke and death: a longitudinal study in Eastern Finland. Am J Epidemiol. 1982;115:526-537.

36. Salonen JT, Slater JS, Tuomilehto J, et al. Leisure time and occupational physical activity: risk of death from ischemic heart disease. Am J Epidemiol. 1988;127:87-94.

37. Sandvik L, Erikssen J, Thaulow E, et al. Physical fitness as a predictor of mortality among healthy, middle-aged Norwegian men. $N$ Engl J Med. 1993;328:533-537.

38. Sesso HD, Paffenbarger RS, Lee I. Physical activity and coronary heart disease in men: the Harvard Alumni Health Study. Circulation. 2000;102:975-980. 
39. Shaper AG, Wannamethee G, Weatherall R. Physical activity and ischemic heart disease in middle-aged British men. Br Heart J. 1991;66:384-394.

40. Shaper AG, Wannamethee G, Walker M. Physical activity, hypertension and risk of heart attack in men without evidence of ischemic heart disease. J Hum Hypertens. 1994;8:3-10.

41. Sherman SE, D'Agostino RB, Silbershatz H, et al. Comparison of past versus recent physical activity in the prevention of premature death and coronary artery disease. Am Heart J. 1999;138(5 pt 1):900-907.

42. Stampfer MJ, Hu FB, Manson JE, et al. Primary prevention of coronary heart disease in women through diet and lifestyle. $N$ Engl $\mathrm{J} \mathrm{Med}$. 2000;343:16-22.

43. Tanasescu M, Leitzmann MF, Rimm EB, et al. Exercise type and intensity in relation: coronary heart disease in men. JAMA. 2002;288:1994-2000.

44. Wagner A, Simon C, Evans A, et al. Physical activity and coronary event incidence in Northern Ireland and France: the Prospective Epidemiological Study of Myocardial Infarction (PRIME). Circulation. 2002; 105:2247-2252.

45. Wannamethee G, Shaper AG. Physical activity and stroke in British middle aged men. BMJ. 1992;304:597-601.

46. Wannamethee G, Shaper AG, Macfarlane PW, et al. Risk factors for sudden cardiac death in middle-aged British men. Circulation. 1995;91:1749-1756

47. Wannamethee G, Whincup PH, Shaper AG, et al. Factors determining case fatality in myocardial infarction: who dies in a heart attack? $\mathrm{Br}$ Heart J. 1995;74:324-331.

48. Wannamethee SG, Shaper AG, Walker M. Changes in physical activity, mortality, and incidence of coronary heart disease in older men. Lancet. 1998;351:1603-1608.

49. Wannamethee SG, Shaper AG, Walker M, et al. Lifestyle and 15-year survival free of heart attack, stroke, and diabetes in middle-aged British men. Arch Intern Med. 1998;158:2433-2440.

50. Wannamethee SG, Shaper AG, Alberti KG. Physical activity, metabolic factors, and the incidence of coronary heart disease and type 2 diabetes. Arch Intern Med. 2000;160:2108-2116.

51. Weller I, Corey P. The impact of excluding non-leisure energy expenditure on the relation between physical activity and mortality in women. Epidemiology. 1998;9:632-635.

52. Yu S, Yarnell JW, Sweetnam PM, et al. What level of physical activity protects against premature cardiovascular death?: the Caerphilly study. Heart. 2003;89:502-506.

\section{Meta-Analyses}

1. Berlin JA, Colditz GA. A meta-analysis of physical activity in the prevention of coronary heart disease. Am J Epidemiol. 1990;132:612-628.

2. Eaton CB. Relation of physical activity and cardiovascular fitness: coronary heart disease, part I: a meta-analysis of the independent relation of physical activity and coronary heart disease. J Am Board Fam Pract. 1992;5:31-42.

3. Haapanen-Niemi N, Vuori I, Pasanen M. Public health burden of coronary heart disease risk factors among middle-aged and elderly men. Prev Med. 1999;28:343-348.

4. Harris TB, Makuc DM, Kleinman JC, et al. Is the serum cholesterol-coronary heart disease relationship modified by activity level in older persons? J Am Geriatr Soc. 1991;39:747-754.

5. Schroll M. Physical activity in an ageing population. Scand J Med Sci Sports. 2003;13:63-69.

6. Williams PT. Physical fitness and activity as separate heart disease risk factors: a meta-analysis: including commentary by Blair SN and Jackson AS. Med Sci Sports Exerc. 2001;33:754-764.

\section{Tobacco Use}

1. Aberg A, Bergstrand R, Johansson S, et al. Cessation of smoking after myocardial infarction: effects on mortality after 10 years. Br Heart $J$. 1983;49:416-422.

2. Gordon T, Kannel WB, McGee D, et al. Death and coronary attacks in men after giving up cigarette smoking: a report from the Framingham study. Lancet. 1974;2:1345-1348.

3. Hasdai D, Garratt KN, Grill DE, et al. Effect of smoking status on the long-term outcome after successful percutaneous coronary revascularization. N Engl J Med. 1997;336:755-761.
4. Helsing KJ, Sandler DP, Comstock GW, et al. Heart disease mortality in nonsmokers living with smokers. Am J Epidemiol. 1988;127:915-922.

5. Hermanson B, Omenn GS, Kronmal RA, et al. Beneficial six-year outcome of smoking cessation in older men and women with coronary artery disease: results from the CASS registry. $N$ Engl J Med. 1988;319:1365-1369.

6. Hirayama T. Lung cancer in Japan: effects of nutrition and passive smoking. In: Mizell M, Correa P, eds. Lung Cancer: Causes and Prevention. New York, NY: Verlag Chemie; 1984:175-195.

7. Hole DJ, Gillis CR, Chopra C, et al. Passive smoking and cardiorespiratory health in a general population in the west of Scotland. BMJ. 1989;299:423-427.

8. Kawachi I, Colditz GA, Stampfer MJ, et al. Smoking cessation and time course of decreased risks of coronary heart disease in middle-aged women. Arch Intern Med. 1994;154:169-175.

9. Morris RW, McCallum AK, Walker M, et al. Cigarette smoking in British men and selection for coronary artery bypass surgery. Heart. 1996;75:557-562.

10. Ockene JK, Kuller LH, Svendsen KH, et al. The relationship of smoking cessation, coronary heart disease, and lung cancer in the Multiple Risk Factor Intervention Trial (MRFIT). Am J Public Health. 1990;80:954-958.

11. Qiao Q, Tervahauta M, Nissinen A, et al. Mortality from all causes and from coronary heart disease related-smoking and changes in smoking during a 35-year follow-up of middle-aged Finnish men. Eur Heart J. 2000;21:1621-1626.

12. Rea TD, Heckbert SR, Kaplan RC, et al. Smoking status and risk for recurrent coronary events after myocardial infarction. Ann Intern Med. 2002;137:494-500. Summary for patients in Ann Intern Med. 2002;137:I34.

13. Shaper AG, Wannamethee SG. Alcohol intake and mortality in middle aged men with diagnosed coronary heart disease. Heart. 2000;83:394-399.

14. Steenland K, Thun M, Lally C, et al. Environmental tobacco smoke and coronary heart disease in the American Cancer Society CPS-II cohort. Circulation. 1996;94:622-628.

15. Svendsen KH, Kuller LH, Martin MJ, et al. Effects of passive smoking in the Multiple Risk Factor Intervention Trial. Am J Epidemiol. 1987;126:783-795.

16. Van Domburg RT, Meeter K, van Berkel DF, et al. Smoking cessation reduces mortality after coronary artery bypass surgery: a 20-year follow-up study. J Am Coll Cardiol. 2000;36:878-883.

\section{Meta-Analyses}

1. Critchley JA, Capewell S. Mortality risk reduction associated with smoking cessation in patients with coronary heart disease: a systematic review. JAMA. 2003;290:86-97.

2. He J, Vupputuri S, Allen K, et al. Passive smoking and the risk of coronary heart disease: a meta-analysis of epidemiologic studies. $N$ Engl J Med. 1999;340:920-926.

3. Law MR, Morris JK, Wald NJ. Environmental tobacco smoke exposure and ischemic heart disease: an evaluation of the evidence. BMJ. 1997;315:973-980.

4. LeVois ME, Layard MW. Publication bias in the environmental tobacco smoke/coronary heart disease epidemiologic literature. Regul Toxicol Pharmacol. 1995;21:184-191.

5. Seltzer CC. Smoking and coronary heart disease in the elderly. Am J Med Sci. 1975;269:309-315.

6. Wilson K, Gibson N, Willan A, et al. Effect of smoking cessation on mortality after myocardial infarction: meta-analysis of cohort studies. Arch Intern Med. 2000;160:939-944.

\section{Antiplatelet Therapy}

1. The aspirin myocardial infarction study: final results. The Aspirin Myocardial Infarction Study research group. Circulation. 1980;62(6 pt 2):V79-V84.

2. Baigent C, Collins R, Appleby P, et al. ISIS-2: 10 year survival among patients with suspected acute myocardial infarction in randomized comparison of intravenous streptokinase, oral aspirin, both, or neither. The ISIS-2 (Second International Study of Infarct Survival) collaborative group. BMJ. 1998;316:1337-1343.

3. Balsano F, Rizzon P, Violi F, et al. Antiplatelet treatment with ticlopidine in unstable angina: a controlled multicenter clinical trial: the Studio della Ticlopidina nell' Angina Instabile Group. Circulation. 1990;82:17-26. 
4. Breddin K, Loew D, Lechner K, et al. The German-Austrian aspirin trial: a comparison of acetylsalicylic acid, placebo and phenprocoumon in secondary prevention of myocardial infarction, on behalf of the GermanAustrian study group. Circulation. 1980;62(6 pt 2):V63-V72.

5. Breddin K, Loew D, Lechner K, et al. Secondary prevention of myocardial infarction: comparison of acetylsalicylic acid, phenprocoumon and placebo: a multicenter two-year prospective study. Thromb Haemost. 1979;41:225-236.

6. Cairns JA, Gent M, Singer J, et al. Aspirin, sulfinpyrazone, or both in unstable angina: results of a Canadian multicenter trial. $N$ Engl J Med. 1985;313:1369-1375.

7. Califf RM, DeLong ER, Ostbye T, et al. Underuse of aspirin in a referral population with documented coronary artery disease. Am J Cardiol. 2002;89:653-661.

8. A randomized, blinded, trial of clopidogrel versus aspirin in patients at risk of ischemic events (CAPRIE): CAPRIE Steering Committee. Lancet. 1996;348:1329-1339.

9. Cohen M, Adams PC, Hawkins L, et al. Usefulness of antithrombotic therapy in resting angina pectoris or non-Q-wave myocardial infarction in preventing death and myocardial infarction: a pilot study from the Antithrombotic Therapy in Acute Coronary Syndromes study group. Am J Cardiol. 1990;66:1287-1292.

10. The coronary drug project aspirin study: implications for clinical care: Coronary Drug Project research group. Prim Care. 1978;5:91-95.

11. Diener HC, Darius H, Bertrand-Hardy JM, et al. Cardiac safety in the European Stroke Prevention Study 2 (ESPS2). Int J Clin Pract. 2001;55:162-163.

12. Elwood PC, Cochrane AL, Burr ML, et al. A randomized controlled trial of acetyl salicylic acid in the secondary prevention of mortality from myocardial infarction. BMJ. 1974;1:436-440.

13. Elwood PC, Sweetnam PM. Aspirin and secondary mortality after myocardial infarction. Lancet. 1979;2(8156-8157):1313-1315.

14. A controlled comparison of aspirin and oral anticoagulants in prevention of death after myocardial infarction. The E.P.S.I.M. Research Group. N Engl J Med. 1982;307:701-708.

15. Gum PA, Thamilarasan M, Watanabe J, et al. Aspirin use and all-cause mortality among patients being evaluated for known or suspected coronary artery disease: a propensity analysis. JAMA. 2001;286:1187-1194, $1249-1250$.

16. Harpaz D, Benderly M, Goldbourt U, et al. Effect of aspirin on mortality in women with symptomatic or silent myocardial ischemia: Israeli BIP study group. Am J Cardiol. 1996;78:1215-1219.

17. Juul-Moller S, Edvardsson N, Jahnmatz B, et al. Double-blind trial of aspirin in primary prevention of myocardial infarction in patients with stable chronic angina pectoris: the Swedish Angina Pectoris Aspirin Trial (SAPAT) group. Lancet. 1992;340:1421-1425.

18. Klimt CR, Knatterud GL, Stamler J, et al. Persantine-Aspirin Reinfarction Study Part II: secondary coronary prevention with persantine and aspirin. J Am Coll Cardiol. 1986;7:251-269.

19. Lewis HD. Unstable angina: status of aspirin and other forms of therapy. Circulation. 1985;72(6 pt 2):V155-V160.

20. Lewis HD, Davis JW, Archibald DG, et al. Protective effects of aspirin against acute myocardial infarction and death in men with unstable angina: results of a Veterans Administration cooperative study. $N$ Engl J Med. 1983;309:396-403.

21. Mehta SR, Yusuf S. The Clopidogrel in Unstable angina-prevent Recurrent Events (CURE) trial program: rationale, design and baseline characteristics including a meta-analysis of the effects of thienopyridines in vascular disease. The Clopidogrel in Unstable angina-prevent Recurrent Events (CURE) Study Investigators. Eur Heart J. 2000;21:2033-2041.

22. Persantine and aspirin in coronary heart disease: the Persantine-Aspirin Reinfarction Study research group. Circulation. 1980;62:449-461.

23. Risk of myocardial infarction and death during treatment with low dose aspirin and intravenous heparin in men with unstable coronary artery disease: the RISC Group. Lancet. 1990;336:827-830.

24. Randomized trial of intravenous streptokinase, oral aspirin, both, or neither among 17,187 cases of suspected acute myocardial infarction: ISIS-2. ISIS-2 (Second International Study of Infarct Survival) collaborative group. J Am Coll Cardiol. 1988;12(6 suppl A):3A-13A.

25. Randomized trial of intravenous streptokinase, oral aspirin, both, or neither among 17,187 cases of suspected acute myocardial infarction: ISIS-2. ISIS-2 (Second International Study of Infarct Survival) collaborative group. Lancet. 1988;2:349-360.
26. Scrutinio D, Cimminiello C, Marubini E, et al. Ticlopidine versus aspirin after myocardial infarction (STAMI) trial. $J$ Am Coll Cardiol. 2001;37:1259-1265.

27. Steinhubl SR, Berger PB, Mann JT, et al. Early and sustained dual oral antiplatelet therapy following percutaneous coronary intervention: a randomized controlled trial. JAMA. 2002;288:2411-2420.

28. Wallentin LC. Aspirin $(75 \mathrm{mg} / \mathrm{d})$ after an episode of unstable coronary artery disease: long-term effects on the risk for myocardial infarction, occurrence of severe angina and the need for revascularization. Research group on Instability in Coronary Artery Disease in Southeast Sweden. J Am Coll Cardiol. 1991;18:1587-1593.

29. White HD, French JK, Hamer AW, et al. Frequent reocclusion of patent infarct-related arteries between 4 weeks and 1 year: effects of antiplatelet therapy. J Am Coll Cardiol. 1995;25:218-223.

30. Yusuf S, Zhao F, Mehta SR, et al. Effects of clopidogrel in addition to aspirin in patients with acute coronary syndromes without ST-segment elevation. N Engl J Med. 2001;345:494-502.

\section{Meta-Analyses}

1. Basinski A, Naylor CD. Aspirin and fibrinolysis in acute myocardial infarction: meta-analytic evidence for synergy. J Clin Epidemiol. 1991;44:1085-1096.

2. Berger PB, Bell MR, Hasdai D, et al. Safety and efficacy of ticlopidine for only 2 weeks after successful intracoronary stent placement. Circulation. 1999;99:248-253.

3. Bhatt DL, Bertrand ME, Berger PB, et al. Meta-analysis of randomized and registry comparisons of ticlopidine with clopidogrel after stenting. J Am Coll Cardiol. 2002;39:9-14.

4. Collins R, MacMahon S, Flather M, et al. Clinical effects of anticoagulant therapy in suspected acute myocardial infarction: systematic overview of randomized trials. BMJ. 1996;313:652-659.

5. Cosmi B, Rubboli A, Castelvetri C, et al. Ticlopidine versus oral anticoagulation for coronary stenting. Cochrane Database of Systematic Reviews. 2001;(4):CD002133.

6. De Schryver EL, Algra A, van Gijn J. Dipyridamole for preventing stroke and other vascular events in patients with vascular disease. Cochrane Database of Systematic Reviews. 2003;(1):CD001820.

7. Every NR, Cannon CP, Granger C, et al. Influence of insurance type on the use of procedures, medications and hospital outcome in patients with unstable angina: results from the GUARANTEE Registry. Global Unstable Angina Registry and Treatment Evaluation. J Am Coll Cardiol. 1998;32:387-392.

8. Hankey GJ, Sudlow CLM, Dunbabin DW. Thienopyridine derivatives (ticlopidine, clopidogrel) versus aspirin for preventing stroke and other serious vascular events in high vascular risk patients. Oxford: The Cochrane Library; 2003;(2):CD001246.

9. He J, Whelton PK, Vu B, et al. Aspirin and risk of hemorrhagic stroke: a meta-analysis of randomized controlled trials. JAMA. 1998;280:1930-1935.

10. Roux S, Christeller S, Ludin E. Effects of aspirin on coronary reocclusion and recurrent ischemia after thrombolysis: a meta-analysis. J Am Coll Cardiol. 1992;19:671-677.

11. Weisman SM, Graham DY. Evaluation of the benefits and risks of low-dose aspirin in the secondary prevention of cardiovascular and cerebrovascular events. Arch Intern Med. 2002;162:2197-2202.

\section{Blood Pressure Management}

1. Alderman MH, Ooi WL, Madhavan S, et al. Treatment-induced blood pressure reduction and the risk of myocardial infarction. JAMA. 1989;262:920-924.

2. Major cardiovascular events in hypertensive patients randomized-doxazosin versus chlorthalidone: the Antihypertensive and Lipid-Lowering treatment to prevent Heart Attack Trial (ALLHAT). ALLHAT collaborative research group. JAMA. 2000;283:1967-1975.

3. Major outcomes in high-risk hypertensive patients randomized to angiotensin-converting enzyme inhibitor or calcium channel blocker versus diuretic: the Antihypertensive and Lipid-Lowering treatment to prevent Heart Attack Trial (ALLHAT). JAMA. 2002;288:2981-2997.

4. Oral captopril versus placebo among 13,634 patients with suspected acute myocardial infarction: interim report from the Chinese Cardiac Study (CCS-1). Lancet. 1995;345:686-687.

5. Avanzini F, Ferrario G, Santoro L, et al. Risks and benefits of early treatment of acute myocardial infarction with an angiotensin-converting 
enzyme inhibitor in patients with a history of arterial hypertension: analysis of the GISSI-3 database. Am Heart J. 2002;144:1018-1025.

6. Brown MJ, Palmer CR, Castaigne A, et al. Morbidity and mortality in patients randomized to double-blind treatment with a long-acting calcium-channel blocker or diuretic in the International Nifedipine GITS study: Intervention as a Goal in Hypertension Treatment (INSIGHT). Lancet. 2000;356:366-372.

7. Casiglia E, Spolaore P, Mazza A, et al. Effect of two different therapeutic approaches on total and cardiovascular mortality in Cardiovascular Study in the Elderly (CASTEL). Jpn Heart J. 1994;35:589-600.

8. Casiglia E, Mazza A, Tikhonoff V, et al. Population-based studies improve outcome in hypertensive patients. Am J Hypertens. 2002;15(7 pt 1):605-608.

9. Dahlof B, Lindholm LH, Hansson L, et al. Morbidity and mortality in the Swedish Trial in Old Patients with Hypertension (STOP-Hypertension). Lancet. 1991;338:1281-1285.

10. Dahlof B, Devereux RB, Kjeldsen SE, et al. Cardiovascular morbidity and mortality in the Losartan Intervention For Endpoint reduction in hypertension study (LIFE): a randomized trial against atenolol. Lancet. 2002;359:995-1003. Summary for patients in: J Fam Pract. 2002;51:599.

11. Dollery C, Brennan PJ. The Medical Research Council Hypertension Trial: the smoking patient. Am Heart J. 1988;115(1 pt 2):276-281.

12. Estacio RO, Jeffers BW, Hiatt WR, et al. The effect of nisoldipine as compared with enalapril on cardiovascular outcomes in patients with non-insulin-dependent diabetes and hypertension. $N$ Engl J Med. 1998;338:645-652.

13. Fletcher AE, Beevers DG, Bulpitt CJ, et al. The relationship between a low treated blood pressure and IHD mortality: a report from the DHSS Hypertension Care Computing Project (DHCCP). J Hum Hypertens. 1988;2:11-15.

14. Gong L, Zhang W, Zhu Y, et al. Shanghai trial of nifedipine in the elderly (STONE). J Hypertens. 1996;14:1237-1245.

15. Hansson L. The Hypertension Optimal Treatment study and the importance of lowering blood pressure. J Hypertens. 1999;17:S9-S13.

16. Hansson L, Lindholm LH, Ekbom T, et al. Randomized trial of old and new antihypertensive drugs in elderly patients: cardiovascular mortality and morbidity. Swedish Trial in Old Patients with Hypertension-2 study. Lancet. 1999;354:1751-1756.

17. Hansson L, Lindholm LH, Niskanen L, et al. Effect of angiotensinconverting-enzyme inhibition compared with conventional therapy on cardiovascular morbidity and mortality in hypertension: the Captopril Prevention Project (CAPPP) randomized trial. Lancet. 1999;353:611-616.

18. Hansson L, Hedner T, Lund-Johansen P, et al. Randomized trial of effects of calcium antagonists compared with diuretics and beta-blockers on cardiovascular morbidity and mortality in hypertension: the Nordic Diltiazem (NORDIL) study. Lancet. 2000;356:359-365.

19. Leren P, Helgeland A. Oslo Hypertension Study. Drugs. 1986;31(suppl 1):41-45.

20. Mehler PS, Coll JR, Estacio R, et al. Intensive blood pressure control reduces the risk of cardiovascular events in patients with peripheral arterial disease and type 2 diabetes. Circulation. 2003;107:753-756.

21. Mortality after $101 / 2$ years for hypertensive participants in the Multiple Risk Factor Intervention Trial: Multiple Risk Factor Intervention Trial research group. Circulation. 1990;82:1616-1628.

22. Randomized double-blind comparison of a calcium antagonist and a diuretic in elderly hypertensives: National Intervention Cooperative Study in Elderly Hypertensives study group. Hypertension. 1999;34:1129-1133.

23. Neaton JD, Grimm RH, Prineas RJ, et al. Treatment of Mild Hypertension Study: final results. Treatment of Mild Hypertension Study research group. JAMA. 1993;270:713-724.

24. Petrovitch H, Vogt TM, Berge KG. Isolated systolic hypertension: lowering the risk of stroke in older patients: SHEP Cooperative Research Group. Geriatrics. 1992;47:30-32, 35-38.

25. Rosei EA, Dal Palu C, Leonetti G, et al. Clinical results of the Verapamil in Hypertension and Atherosclerosis Study: VHAS Investigators. J Hypertens. 1997;15:1337-1344.

26. Sigurdsson JA, Bengtsson C, Lapidus L, et al. Morbidity and mortality in relation to blood pressure and antihypertensive treatment: a 12-year follow-up study of a population sample of Swedish women. Acta Med Scand. 1984;215:313-322.

27. Staessen JA, Fagard R, Thijs L, et al. Randomized double-blind comparison of placebo and active treatment for older patients with isolated systolic hypertension: the Systolic Hypertension in Europe (Syst-Eur) trial investigators. Lancet. 1997;350:757-764.

28. Efficacy of atenolol and captopril in reducing risk of macrovascular and microvascular complications in type 2 diabetes: UKPDS 39. UK Prospective Diabetes Study Group. BMJ. 1998;317:713-720.
29. Wikstrand J, Warnold I, Olsson G, et al. Primary prevention with metoprolol in patients with hypertension: mortality results from the MAPHY study. JAMA. 1988;259:1976-1982.

30. Wilhelmsen L, Berglund G, Elmfeldt D, et al. Beta-blockers versus diuretics in hypertensive men: main results from the HAPPHY trial. J Hypertens. 1987;5:561-572.

31. Wu N, Fan Z. Secondary prevention of cardiac events following myocardial infarction: effects of atenolol and enalapril. Beijing collaborative study group. Zhonghua Yi Xue Za Zhi (Chinese Medical Journal). 1997;110:602-606.

\section{Meta-Analyses}

1. Bath P. Blood pressure-lowering for secondary prevention of stroke: ACE inhibition is not the key. Stroke. 2003;34:1334-1335.

2. Cox JP, O'Brien ET, O'Malley K. Treatment of elderly hypertensives: results and implications of recent trials. J Cardiovasc Pharmacol. 1987; 10(suppl 2):S65-S70.

3. He J, Whelton PK. Elevated systolic blood pressure as a risk factor for cardiovascular and renal disease. J Hypertens. 1999;17(suppl 2):S7-S13.

4. Holme I, Ekelund LG, Hjermann I, et al. Quality-adjusted meta-analysis of the hypertension/coronary dilemma. Am J Hypertens. 1994;7:703-712.

5. Kloner RA, Vetrovec GW, Materson BJ, et al. Safety of long-acting dihydropyridine calcium channel blockers in hypertensive patients. Am J Cardiol. 1998;81:163-169.

6. Law MR, Wald NJ, Morris JK, et al. Value of low dose combination treatment with blood pressure lowering drugs: analysis of 354 randomized trials. BMJ. 2003;326:1427.

7. Miall WE. Beta-blockers versus thiazides in the treatment of hypertension: a review of the experience of the large national trials. J Cardiovasc Pharmacol. 1990;16(suppl 5):S58-S63.

8. Mulrow C, Lau J, Cornell J, et al. Pharmacotherapy for hypertension in the elderly. Oxford: The Cochrane Library; 2003;(2):CD000028.

9. Neal B, MacMahon S. An overview of 37 randomized trials of blood pressure lowering agents among 270,000 individuals: World Health Organization-International Society of Hypertension Blood Pressure Lowering Treatment trialists' collaboration. Clin Exp Hypertens. 1999;21:517-529.

10. Neal B, MacMahon S, Chapman N, et al. Effects of ACE inhibitors, calcium antagonists, and other blood-pressure-lowering drugs: results of prospectively designed overviews of randomized trials. Blood Pressure Lowering Treatment trialists' collaboration. Lancet. 2000;356:1955-1964.

11. O’Donnell CJ, Kannel WB. Cardiovascular risks of hypertension: lessons from observational studies. J Hypertens. 1998;16(suppl 6):S3-S7.

12. Opie LH, Schall R. Evidence-based evaluation of calcium channel blockers for hypertension: equality of mortality and cardiovascular risk relative to conventional therapy. J Am Coll Cardiol. 2002;39:315-322.

13. Pahor M, Psaty BM, Alderman MH, et al. Health outcomes associated with calcium antagonists compared with other first-line antihypertensive therapies: a meta-analysis of randomized controlled trials. Lancet. 2000;356:1949-1954.

14. Psaty BM, Smith NL, Siscovick DS, et al. Health outcomes associated with antihypertensive therapies used as first-line agents: a systematic review and meta-analysis. JAMA. 1997;277:739-745.

15. Shinton RA, Beevers DG. A meta-analysis of mortality and coronary prevention in hypertensive patients treated with beta-receptor blockers. $J$ Hum Hypertens. 1990;4(suppl 2):31-34.

16. Whelton PK, Williamson JD, Louis GT, et al. Experimental approaches to determining the choice of first-step therapy for patients with hypertension: the ALLHAT research group. Antihypertensive and LipidLowering treatment to prevent Heart Attack Trial. Clin Exp Hypertens. 1996;18:569-579.

\section{$\beta$-Blocker Therapy}

1. Randomized, placebo-controlled trial of carvedilol in patients with congestive heart failure due to ischemic heart disease: Australia/New Zealand Heart Failure Research collaborative group. Lancet. 1997;349:375-380.

2. A randomized trial of propranolol in patients with acute myocardial infarction: I. Mortality results: the beta-Blocker Heart Attack Trial (BHAT) investigator group. JAMA. 1982;247:1707-1714.

3. The Cardiac Insufficiency Bisoprolol Study II (CIBIS-II): a randomized trial. Lancet. 1999;353:9-13.

4. Basu S, Senior R, Raval U, et al. Beneficial effects of intravenous and oral carvedilol treatment in acute myocardial infarction: a placebocontrolled, randomized trial. Circulation. 1997;96:183-191. 
5. Boissel JP, Leizorovicz A, Picolet $\mathrm{H}$, et al. Secondary prevention after high-risk acute myocardial infarction with low-dose acebutolol. Am J Cardiol. 1990;66:251-260.

6. Chan AW, Quinn MJ, Bhatt DL, et al. Mortality benefit of beta-blockade after successful elective percutaneous coronary intervention. J Am Coll Cardiol. 2002;40:669-675.

7. A randomized trial of beta-blockade in heart failure: the Cardiac Insufficiency Bisoprolol Study (CIBIS). CIBIS investigators and committees. Circulation. 1994;90:1765-1773.

8. Dahlof B, Devereux RB, Kjeldsen SE, et al. Cardiovascular morbidity and mortality in the Losartan Intervention For Endpoint reduction in hypertension study (LIFE): a randomized trial against atenolol. Lancet. 2002;359:995-1003. Summary for patients in: J Fam Pract. 2002;51:599.

9. Randomized trial of intravenous atenolol among 16,027 cases of suspected acute myocardial infarction: ISIS-1. First International Study of Infarct Survival collaborative group. Lancet. 1986;2:57-66.

10. Herlitz J, Bengtson A, Wiklund I, et al. Morbidity and quality of life 5 years after early intervention with metoprolol in suspected acute myocardial infarction. Cardiology. 1988;75:357-364.

11. Hjalmarson A, Elmfeldt D, Herlitz J, et al. Effect on mortality of metoprolol in acute myocardial infarction: a double-blind randomized trial. Lancet. 1981;2:823-827.

12. Jonas M, Reicher-Reiss H, Boyko V, et al. Usefulness of beta-blocker therapy in patients with non-insulin-dependent diabetes mellitus and coronary artery disease: Bezafibrate Infarction Prevention (BIP) study group. Am J Cardiol. 1996;77:1273-1277.

13. Julian DG, Prescott RJ, Jackson FS, et al. Controlled trial of sotalol for one year after myocardial infarction. Lancet. 1982;1:1142-1147.

14. Lindholm LH, Ibsen H, Dahlof B, et al. Cardiovascular morbidity and mortality in patients with diabetes in the Losartan Intervention For Endpoint reduction in hypertension study (LIFE): a randomized trial against atenolol. Lancet. 2002;359:1004-1010.

15. The Lopressor Intervention Trial: multicenter study of metoprolol in survivors of acute myocardial infarction. Lopressor Intervention Trial research group. Eur Heart J. 1987;8:1056-1064.

16. Effect of metoprolol on death and cardiac events during a 2-year period after coronary artery bypass grafting: the MACB study group. Eur Heart J. 1995;16:1825-1832.

17. Improvement in prognosis of myocardial infarction by long-term betaadrenoreceptor blockade using practolol: a multicenter international study. BMJ. 1975;3:735-740.

18. A multicenter study on timolol in secondary prevention after myocardial infarction: the Norwegian Multicenter Study Group. Acta Medica Scandinavica - Supplementum. 1983;674:1-129.

19. Packer M, Coats AJ, Fowler MB, et al. Effect of carvedilol on survival in severe chronic heart failure. N Engl J Med. 2001;344:1651-1658.

20. Pepine CJ, Cohn PF, Deedwania PC, et al. Effects of treatment on outcome in mildly symptomatic patients with ischemia during daily life: the Atenolol Silent Ischemia Study (ASIST). Circulation. 1994;90:762-768.

21. Poldermans D, Boersma E, Bax JJ, et al. Bisoprolol reduces cardiac death and myocardial infarction in high-risk patients as long as 2 years after successful major vascular surgery. Eur Heart J. 2001;22:1353-1358.

22. Rochon PA, Tu JV, Anderson GM, et al. Rate of heart failure and 1-year survival for older people receiving low-dose beta-blocker therapy after myocardial infarction. Lancet. 2000;356:639-644.

23. Salathia KS, Barber JM, McIlmoyle EL, et al. Very early intervention with metoprolol in suspected acute myocardial infarction. Eur Heart J. 1985;6:190-198.

24. Sleight P. Beta blockade early in acute myocardial infarction. Am J Cardiol. 1987;60:6A-10A.

25. Comparison of invasive and conservative strategies after treatment with intravenous tissue plasminogen activator in acute myocardial infarction: results of the thrombolysis in myocardial infarction (TIMI) phase II trial. TIMI study group. $N$ Engl J Med. 1989;320:618-627.

26. Tight blood pressure control and risk of macrovascular and microvascular complications in type 2 diabetes: UKPDS 38. UK Prospective Diabetes Study Group. BMJ. 1998;317:703-713. Erratum in: BMJ. 1999;318:29.

27. Wikstrand J, Warnold I, Olsson G, et al. Primary prevention with metoprolol in patients with hypertension: mortality results from the MAPHY study. JAMA. 1988;259:1976-1982.

28. Wilhelmsen L, Berglund G, Elmfeldt D, et al. Beta-blockers versus diuretics in hypertensive men: main results from the HAPPHY trial. J Hypertens. 1987;5:561-572.
29. Wu N, Fan Z. Secondary prevention of cardiac events following myocardial infarction: effects of atenolol and enalapril. Beijing collaborative study group. Zhonghua Yi Xue Za Zhi (Chinese Medical Journal). 1997; 110:602-606.

30. Yusuf S, Ramsdale D, Peto R, et al. Early intravenous atenolol treatment in suspected acute myocardial infarction: preliminary report of a randomized trial. Lancet. 1980;2:273-276.

\section{Meta-Analyses}

1. Andrews TC, Reimold SC, Berlin JA, et al. Prevention of supraventricular arrhythmias after coronary artery bypass surgery: a meta-analysis of randomized control trials. Circulation. 1991;84(5 suppl):III236-III244.

2. Auerbach AD, Goldman L. Beta-blockers and reduction of cardiac events in noncardiac surgery: scientific review. JAMA. 2002;287:1435-1444.

3. Baber NS, Lewis JA. Confidence in results of beta-blocker postinfarction trials. Br Med J (Clin Res Ed). 1982;284:1749-1750.

4. The Beta-Blocker Pooling Project (BBPP): subgroup findings from randomized trials in post infarction patients. Beta-Blocker Pooling Project research group. Eur Heart J. 1988;9:8-16.

5. Freemantle N, Cleland J, Young P, et al. Beta blockade after myocardial infarction: systematic review and meta regression analysis. BMJ. 1999;318:1730-1737.

6. Herlitz J, Dellborg M, Karlson BW, et al. Similar risk reduction of death of extended-release metoprolol once daily and immediate-release metoprolol twice daily during 5 years after myocardial infarction. Cardiovasc Drugs Ther. 1999;13:127-135.

7. Hjalmarson A. Prevention of sudden cardiac death with beta blockers. Clin Cardiol. 1999;22(suppl 5):V11-V15.

8. Houghton T, Freemantle N, Cleland JG. Are beta-blockers effective in patients who develop heart failure soon after myocardial infarction?: a meta-regression analysis of randomized trials. Eur $J$ Heart Failure. 2000;2:333-340.

9. Olsson G, Wikstrand J, Warnold I, et al. Metoprolol-induced reduction in postinfarction mortality: pooled results from five double-blind randomized trials. Eur Heart J. 1992;13:28-32.

10. Psaty BM, Smith NL, Siscovick DS, et al. Health outcomes associated with antihypertensive therapies used as first-line agents: a systematic review and meta-analysis. JAMA. 1997;277:739-745.

11. Shinton RA, Beevers DG. A meta-analysis of mortality and coronary prevention in hypertensive patients treated with beta-receptor blockers. $J$ Hum Hypertens. 1990;4(suppl 2):31-34.

12. Wagner G. Summary of short- and long-term studies with bisoprolol in coronary heart disease (CHD). J Cardiovasc Pharmacol. 1986;8(suppl 11):S160-S166.

\section{Cardiac Rehabilitation}

1. Belardinelli R, Paolini I, Cianci G, et al. Exercise training intervention after coronary angioplasty: the ETICA trial. J Am Coll Cardiol. 2001;37:1891-1900.

2. Carson P, Phillips R, Lloyd M, et al. Exercise after myocardial infarction: a controlled trial. J R Coll Physicians Lond. 1982;16:147-151.

3. Dugmore LD, Tipson RJ, Phillips MH, et al. Changes in cardiorespiratory fitness, psychological wellbeing, quality of life, and vocational status following a 12 month cardiac exercise rehabilitation program. Heart. 1999;81:359-366.

4. Fridlund B, Pihlgren C, Wannestig L. A supportive-educative caring rehabilitation program; improvements of physical health after myocardial infarction. J Clin Nurs. 1992;1:141-146.

5. Hakkila J. Morbidity and mortality after myocardial infarction. Bibl Cardiol. 1976;36:159-163.

6. Hamalainen H, Luurila OJ, Kallio V, et al. Reduction in sudden deaths and coronary mortality in myocardial infarction patients after rehabilitation: 15 year follow-up study. Eur Heart J. 1995;16:1839-1844.

7. Haskell WL, Alderman EL, Fair JM, et al. Effects of intensive multiple risk factor reduction on coronary atherosclerosis and clinical cardiac events in men and women with coronary artery disease: the Stanford Coronary Risk Intervention Project (SCRIP). Circulation. 1994;89:975-990.

8. Kallio V, Hamalainen H, Hakkila J, et al. Reduction in sudden deaths by a multifactorial intervention program after acute myocardial infarction. Lancet. 1979;2:1091-1094.

9. Lidell E, Fridlund B. Long-term effects of a comprehensive rehabilitation program after myocardial infarction. Scand J Caring Sci. 1996;10:67-74. 
10. Marra S, Paolillo V, Spadaccini F, et al. Long-term follow-up after a controlled randomized post-myocardial infarction rehabilitation program: effects on morbidity and mortality. Eur Heart J. 1985;6:656-663.

11. Naughton J, Dorn J, Imamura D. Outcomes measurement in cardiac rehabilitation: the National Exercise and Heart Disease Project. Journal of Rehabilitation Outcomes Measurement. 2000;4:64-75.

12. Ornish D, Scherwitz LW, Billings JH, et al. Intensive lifestyle changes for reversal of coronary heart disease. JAMA. 1998;280:2001-2007.

13. Comparison of a rehabilitation program, a counseling program and usual care after an acute myocardial infarction: results of a long-term randomized trial: PRECOR group. Eur Heart J. 1991;12:612-616.

14. Rechnitzer PA, Cunningham DA, Andrew GM, et al. Relation of exercise to the recurrence rate of myocardial infarction in men: Ontario Exercise-Heart Collaborative Study. Am J Cardiol. 1983;51:65-69.

15. Roman O, Gutierrez M, Luksic I, et al. Cardiac rehabilitation after acute myocardial infarction: 9-year controlled follow-up study. Cardiology. 1983;70:223-231.

16. Shaw LW. Effects of a prescribed supervised exercise program on mortality and cardiovascular morbidity in patients after myocardial infarction: the National Exercise and Heart Disease Project. Am J Cardiol. 1981;48:39-46.

17. Specchia G, De Servi S, Scire A, et al. Interaction between exercise training and ejection fraction in predicting prognosis after a first myocardial infarction. Circulation. 1996;94:978-982.

18. Vermeulen A, Lie KI, Durrer D. Effects of cardiac rehabilitation after myocardial infarction: changes in coronary risk factors and long-term prognosis. Am Heart J. 1983;105:798-801.

19. Wallner S, Watzinger N, Lindschinger M, et al. Effects of intensified lifestyle modification on the need for further revascularization after coronary angioplasty. Eur J Clin Invest. 1999;29:372-379.

\section{Meta-Analyses}

1. Bobbio M. Does post myocardial infarction rehabilitation prolong survival?: a meta-analytic survey. G Ital Cardiol. 1989;19:1059-1067.

2. Jolliffe JA, Rees K, Taylor RS, et al. Exercise-Based Rehabilitation for Coronary Heart Disease. Oxford: The Cochrane Library; 2003;(2):CD001800

3. O'Connor GT, Buring JE, Yusuf S, et al. An overview of randomized trials of rehabilitation with exercise after myocardial infarction. Circulation. 1989;80:234-244.

4. Oldridge NB, Guyatt GH, Fischer ME, et al. Cardiac rehabilitation after myocardial infarction: combined experience of randomized clinical trials. JAMA. 1988;260:945-950.

\section{ACE/ARB Therapy}

1. Ambrosioni E, Borghi C, Magnani B. The effect of the angiotensinconverting-enzyme inhibitor zofenopril on mortality and morbidity after anterior myocardial infarction: the Survival of Myocardial Infarction Long-Term Evaluation (SMILE) study investigators. $N$ Engl $\mathrm{J} \mathrm{Med}$. 1995;332:80-85.

2. Effect of ramipril on mortality and morbidity of survivors of acute myocardial infarction with clinical evidence of heart failure: the Acute Infarction Ramipril Efficacy (AIRE) study investigators. Lancet. 1993;342:821-828.

3. Borghi C, Marino P, Zardini P, et al. Short- and long-term effects of early fosinopril administration in patients with acute anterior myocardial infarction undergoing intravenous thrombolysis: results from the Fosinopril in Acute Myocardial Infarction Study. FAMIS working party. Am Heart J. 1998;136:213-225.

4. Oral captopril versus placebo among 13,634 patients with suspected acute myocardial infarction: interim report from the Chinese Cardiac Study (CCS-1): Chinese Cardiac Study (CCS-1) investigators. Lancet. 1995;345:686-687.

5. Coletta C, Ricci R, Ceci V, et al. Effects of early treatment with captopril and metoprolol singly or together on six-month mortality and morbidity after acute myocardial infarction: results of the RIMA (Rimodellamento Infarto Miocardico Acuto) study: the RIMA researchers. G Ital Cardiol. 1999;29:115-124; discussion 125-129.

6. Dahlof B, Devereux RB, Kjeldsen SE, et al. Cardiovascular morbidity and mortality in the Losartan Intervention For Endpoint reduction in hypertension study (LIFE): a randomized trial against atenolol. Lancet. 2002;359:995-1003.

7. Dickstein K, Kjekshus J. Effects of losartan and captopril on mortality and morbidity in high-risk patients after acute myocardial infarction: the OPTIMAAL randomized trial: steering committee of the OPTIMAAL study group. Optimal Trial In Myocardial infarction with Angiotensin II Antagonist Losartan. Lancet. 2002;360:752-760.

8. Ellis SG, Lincoff AM, Whitlow PL, et al. Evidence that angiotensinconverting enzyme inhibitor use diminishes the need for coronary revascularization after stenting. Am J Cardiol. 2002;89:937-940.

9. Efficacy of perindopril in reduction of cardiovascular events among patients with stable coronary artery disease: randomized, double-blind, placebo-controlled, multicenter trial (the EUROPA study). EURopean trial On reduction of cardiac events with Perindopril in stable coronary Artery disease investigators. Lancet. 2003;362:782-788.

10. French JK, Amos DJ, Williams BF, et al. Effects of early captopril administration after thrombolysis on regional wall motion in relation to infarct artery blood flow. J Am Coll Cardiol. 1999;33:139-145.

11. GISSI-3: effects of lisinopril and transdermal glyceryl trinitrate singly and together on 6-week mortality and ventricular function after acute myocardial infarction. Gruppo Italiano per lo Studio della Sopravvivenza nell'Infarto miocardico. Lancet. 1994;343:1115-1122.

12. Six-month effects of early treatment with lisinopril and transdermal glyceryl trinitrate singly and together withdrawn six weeks after acute myocardial infarction: the GISSI-3 trial. Gruppo Italiano per lo Studio della Sopravvivenza nell'Infarto miocardico. J Am Coll Cardiol. 1996;27:337-344.

13. Hansson L, Lindholm LH, Niskanen L, et al. Effect of angiotensinconverting-enzyme inhibition compared with conventional therapy on cardiovascular morbidity and mortality in hypertension: the Captopril Prevention Project (CAPPP) randomized trial. Lancet. 1999;353:611-616.

14. ISIS-4: a randomized factorial trial assessing early oral captopril, oral mononitrate, and intravenous magnesium sulfate in 58,050 patients with suspected acute myocardial infarction. ISIS-4 (Fourth International Study of Infarct Survival) collaborative group. Lancet. 1995;345:669-685.

15. Kober L, Torp-Pedersen C, Carlsen JE, et al. A clinical trial of the angiotensin-converting-enzyme inhibitor trandolapril in patients with left ventricular dysfunction after myocardial infarction: Trandolapril Cardiac Evaluation (TRACE) study group. N Engl J Med. 1995;333:1670-1676.

16. Lonn E, Roccaforte R, Yi Q, et al. Effect of long-term therapy with ramipril in high-risk women. J Am Coll Cardiol. 2002;40:693-702.

17. Pfeffer MA, McMurray JJV, Velazquez, et al. Valsartan, captopril, or both in myocardial infarction complicated by heart failure, left ventricular dysfunction, or both: the Valsartan in Acute Myocardial Infarction trial investigators. N Engl J Med. 2003;349:1893-1906.

18. Pitt B, O'Neill B, Feldman R, et al. The Quinapril Ischemic Event Trial (QUIET): evaluation of chronic ACE inhibitor therapy in patients with ischemic heart disease and preserved left ventricular function. Am J Cardiol. 2001;87:1058-1063.

19. Swedberg K, Held P, Kjekshus J, et al. Effects of the early administration of enalapril on mortality in patients with acute myocardial infarction: results of the Cooperative New Scandinavian Enalapril Survival Study II (CONSENSUS II). N Engl J Med. 1992;327:678-684.

20. Teo KK, Burton JR, Buller CE, et al. Long-term effects of cholesterol lowering and angiotensin-converting enzyme inhibition on coronary atherosclerosis: the Simvastatin/Enalapril Coronary Atherosclerosis Trial (SCAT). Circulation. 2000;102:1748-1754.

21. Yusuf S, Sleight P, Pogue J, et al. Effects of an angiotensin-convertingenzyme inhibitor, ramipril, on cardiovascular events in high-risk patients: the Heart Outcomes Prevention Evaluation study investigators. $N$ Engl J Med. 2000;342:145-153.

\section{Meta-Analyses}

1. Indications for ACE inhibitors in the early treatment of acute myocardial infarction: systematic overview of individual data from 100,000 patients in randomized trials. ACE Inhibitor Myocardial Infarction collaborative group. Circulation. 1998;97:2202-2212.

2. Borghi C, Ambrosioni E. Clinical aspects of ACE inhibition in patients with acute myocardial infarction. Cardiovasc Drugs Ther. 1996;10:519-525.

3. Domanski MJ, Exner DV, Borkowf CB, et al. Effect of angiotensin converting enzyme inhibition on sudden cardiac death in patients following acute myocardial infarction: a meta-analysis of randomized clinical trials. J Am Coll Cardiol. 1999;33:598-604.

4. Flather MD, Lonn EM, Yusuf S. Effects of ACE inhibitors on mortality when started in the early phase of myocardial infarction: evidence from the larger randomized controlled trials. J Cardiovasc Risk. 1995;2:423-428.

5. Hall AS, Ball SG. ACE-inhibitor therapy after myocardial infarction: a new treatment strategy. Z Kardiol. 1994;83(suppl 4):57-62. 
6. Neal B, MacMahon S, Chapman N, et al. Effects of ACE inhibitors, calcium antagonists, and other blood-pressure-lowering drugs: results of prospectively designed overviews of randomized trials. Blood Pressure Lowering Treatment trialists' collaboration. Lancet. 2000;356:1955-1964.

7. Teo KK, Yusuf S, Pfeffer M, et al. Effects of long-term treatment with angiotensin-converting-enzyme inhibitors in the presence or absence of aspirin: a systematic review. Lancet. 2002;360:1037-1043.

\section{Weight Management}

1. Harris TB, Ballard-Barbasch R, Madans J, et al. Overweight, weight loss, and risk of coronary heart disease in older women: the NHANES I epidemiologic follow-up study. Am J Epidemiol. 1993;137:1318-1327.

2. Harris TB, Launer LJ, Madans J, et al. Cohort study of effect of being overweight and change in weight on risk of coronary heart disease in old age. BMJ. 1997;314:1791-1794.

3. Manson JE, Willett WC, Stampfer MJ, et al. Body weight and mortality among women. $N$ Engl J Med. 1995;333:677-685.

4. Paffenbarger RS, Hyde RT, Wing AL, et al. The association of changes in physical-activity level and other lifestyle characteristics with mortality among men. $N$ Engl J Med. 1993;328:538-545.

5. Singh RB, Rastogi V, Rastogi SS, et al. Effect of diet and moderate exercise on central obesity and associated disturbances, myocardial infarction and mortality in patients with and without coronary artery disease. J Am Coll Nutr. 1996;15:592-601.

6. Walker M, Wannamethee G, Whincup PH, et al. Weight change and risk of heart attack in middle-aged British men. Int J Epidemiol. 1995;24:694-703.

\section{Meta-Analyses}

1. Anderson JW, Konz EC. Obesity and disease management: effects of weight loss on comorbid conditions. Obes Res. 2001;9(suppl 4):326S-334S.

\section{Diabetes}

1. Abraira C, Colwell J, Nuttall F, et al. Cardiovascular events and correlates in the Veterans Affairs Diabetes Feasibility Trial: Veterans Affairs cooperative study on glycemic control and complications in type II diabetes. Arch Intern Med. 1997;157:181-188.

2. Effect of intensive diabetes management on macrovascular events and risk factors in the Diabetes Control and Complications Trial. Am J Cardiol. 1995;75:894-903.

3. Gaede P, Vedel P, Larsen N, et al. Multifactorial intervention and cardiovascular disease in patients with type 2 diabetes. $N$ Engl J Med. 2003;348:383-393.

4. Hu FB, Stampfer MJ, Solomon C, et al. Physical activity and risk for cardiovascular events in diabetic women. Ann Intern Med. 2001;134:96-105.

5. Malmberg K. Prospective randomized study of intensive insulin treatment on long term survival after acute myocardial infarction in patients with diabetes mellitus: DIGAMI (Diabetes Mellitus, Insulin Glucose Infusion in Acute Myocardial Infarction) study group. BMJ. 1997;314:1512-1515.

6. Malmberg K, Ryden L, Hamsten A, et al. Effects of insulin treatment on cause-specific one-year mortality and morbidity in diabetic patients with acute myocardial infarction: DIGAMI study group. Diabetes Insulin-Glucose in Acute Myocardial Infarction. Eur Heart J. 1996;17:1337-1344.

7. Effect of intensive blood-glucose control with metformin on complications in overweight patients with type 2 diabetes (UKPDS 34): UK Prospective Diabetes Study (UKPDS) Group. Lancet. 1998;352:854-865.

8. Intensive blood-glucose control with sulfonylureas or insulin compared with conventional treatment and risk of complications in patients with type 2 diabetes (UKPDS 33): UK Prospective Diabetes Study (UKPDS) Group. Lancet. 1998;352:837-853.

\section{Meta-Analyses}

1. Genuth S. Exogenous insulin administration and cardiovascular risk in non-insulin-dependent and insulin-dependent diabetes mellitus. Ann Intern Med. 1996;124(1 pt 2):104-109.

2. Tudor-Locke CE, Bell RC, Myers AM. Revisiting the role of physical activity and exercise in the treatment of type 2 diabetes. Can J Appl Physiol. 2000;25:466-491.

\section{Hormone Replacement Therapy}

1. Alexander KP, Newby LK, Hellkamp AS, et al. Initiation of hormone replacement therapy after acute myocardial infarction is associated with more cardiac events during follow-up. J Am Coll Cardiol. 2001;38:1-7.

2. Angeja BG, Shlipak MG, Go AS, et al. Hormone therapy and the risk of stroke after acute myocardial infarction in postmenopausal women. $J \mathrm{Am}$ Coll Cardiol. 2001;38:1297-1301.

3. Bush TL, Barrett-Connor E, Cowan LD, et al. Cardiovascular mortality and noncontraceptive use of estrogen in women: results from the Lipid Research Clinics Program follow-up study. Circulation. 1987;75:1102-1109.

4. Cauley JA, Seeley DG, Browner WS, et al. Estrogen replacement therapy and mortality among older women: the study of osteoporotic fractures. Arch Intern Med. 1997;157:2181-2187.

5. Cherry N, Gilmour K, Hannaford P, et al. Estrogen therapy for prevention of reinfarction in postmenopausal women: a randomized placebo controlled trial. Lancet. 2002;360:2001-2008.

6. The Coronary Drug Project: findings leading to discontinuation of the 2.5-mg day estrogen group. Coronary Drug Project research group. JAMA. 1973;226:652-657.

7. Criqui MH, Suarez L, Barrett-Connor E, et al. Postmenopausal estrogen use and mortality: results from a prospective study in a defined, homogeneous community. Am J Epidemiol. 1988;128:606-614.

8. Falkeborn M, Persson I, Adami HO, et al. The risk of acute myocardial infarction after estrogen and estrogen-progestogen replacement. $\mathrm{Br} J$ Obstet Gynaecol. 1992;99:821-828.

9. Folsom AR, Mink PJ, Sellers TA, et al. Hormonal replacement therapy and morbidity and mortality in a prospective study of postmenopausal women. Am J Public Health. 1995;85(8 pt 1):1128-1132.

10. Grady D, Herrington D, Bittner V, et al. Cardiovascular disease outcomes during 6.8 years of hormone therapy: Heart and Estrogen/progestin Replacement Study follow-up (HERS II). JAMA. 2002;288:49-57.

11. Grodstein F, Stampfer MJ, Manson JE, et al. Postmenopausal estrogen and progestin use and the risk of cardiovascular disease. $N$ Engl J Med. 1996;335:453-461. Erratum in: $N$ Engl J Med. 1996;335:1406.

12. Grodstein F, Stampfer MJ, Colditz GA, et al. Postmenopausal hormone therapy and mortality. $N$ Engl J Med. 1997;336:1769-1775.

13. Grodstein F, Manson JE, Colditz GA, et al. A prospective, observational study of postmenopausal hormone therapy and primary prevention of cardiovascular disease. Ann Intern Med. 2000;133:933-941.

14. Grodstein F, Manson JE, Stampfer MJ. Postmenopausal hormone use and secondary prevention of coronary events in the Nurses' Health Study: a prospective, observational study. Ann Intern Med. 2001;135:1-8, I29.

15. Heckbert SR, Weiss NS, Koepsell TD, et al. Duration of estrogen replacement therapy in relation to the risk of incident myocardial infarction in postmenopausal women. Arch Intern Med. 1997;157:1330-1336.

16. Hedblad B, Merlo J, Manjer J, et al. Incidence of cardiovascular disease, cancer and death in postmenopausal women affirming use of hormone replacement therapy. Scand J Public Health. 2002;30:12-19.

17. Henderson BE, Paganini-Hill A, Ross RK. Decreased mortality in users of estrogen replacement therapy. Arch Intern Med. 1991;151:75-78.

18. Hu FB, Stampfer MJ, Manson JE, et al. Trends in the incidence of coronary heart disease and changes in diet and lifestyle in women. $N$ Engl J Med. 2000;343:530-537.

19. Hulley S, Grady D, Bush T, et al. Randomized trial of estrogen plus progestin for secondary prevention of coronary heart disease in postmenopausal women: Heart and Estrogen/progestin Replacement Study (HERS) research group. JAMA. 1998;280:605-613.

20. Manson JE, Hsia J, Johnson KC, et al. Estrogen plus progestin and the risk of coronary heart disease. $N$ Engl J Med. 2003;349:523-534.

21. Nachtigall LE, Nachtigall RH, Nachtigall RD, et al. Estrogen replacement therapy II: a prospective study in the relationship to carcinoma and cardiovascular and metabolic problems. Obstet Gynecol. 1979;54:74-79.

22. Pedersen AT, Lidegaard O, Kreiner S, et al. Hormone replacement therapy and risk of non-fatal stroke. Lancet. 1997;350:1277-1283.

23. Petitti DB, Perlman JA, Sidney S. Noncontraceptive estrogens and mortality: long-term follow-up of women in the Walnut Creek Study. Obstet Gynecol. 1987;70(3 pt 1):289-293.

24. Psaty BM, Heckbert SR, Atkins D, et al. The risk of myocardial infarction associated with the combined use of estrogens and progestins in postmenopausal women. Arch Intern Med. 1994;154:1333-1339.

25. Rodriguez C, Calle EE, Patel AV, et al. Effect of body mass on the association between estrogen replacement therapy and mortality among elderly US women. Am J Epidemiol. 2001;153:145-152. 
26. Rosenberg L, Armstrong B, Jick H. Myocardial infarction and estrogen therapy in post-menopausal women. N Engl J Med. 1976;294:1256-1259.

27. Rosenberg L, Palmer JR, Shapiro S. A case-control study of myocardial infarction in relation to use of estrogen supplements. Am J Epidemiol. 1993; 137:54-63.

28. Shlipak MG, Angeja BG, Go AS, et al. Hormone therapy and in-hospital survival after myocardial infarction in postmenopausal women. Circulation. 2001;104:2300-2304.

29. Simon JA, Hsia J, Cauley JA, et al. Postmenopausal hormone therapy and risk of stroke: the Heart and Estrogen-progestin Replacement Study (HERS). Circulation. 2001;103:638-642.

30. Sourander L, Rajala T, Raiha I, et al. Cardiovascular and cancer morbidity and mortality and sudden cardiac death in postmenopausal women on estrogen replacement therapy (ERT). Lancet. 1998;352:1965-1969.

31. Stamler J. The coronary drug project-findings with regard to estrogen, dextrothyroxine, clofibrate and niacin. Adv Exp Med Biol. 1977;82:52-75.

32. Stampfer MJ, Colditz GA, Willett WC, et al. Postmenopausal estrogen therapy and cardiovascular disease: ten-year follow-up from the nurses' health study. N Engl J Med. 1991;325:756-762.

33. Sturgeon SR, Schairer C, Brinton LA, et al. Evidence of a healthy estrogen user survivor effect. Epidemiology. 1995;6:227-231.

34. Sullivan JM, Vander Zwaag R, Hughes JP, et al. Estrogen replacement and coronary artery disease: effect on survival in postmenopausal women. Arch Intern Med. 1990;150:2557-2562.

35. Thompson SG, Meade TW, Greenberg G. The use of hormonal replacement therapy and the risk of stroke and myocardial infarction in women. J Epidemiol Community Health. 1989;43:173-178.

36. Varas-Lorenzo C, Garcia-Rodriguez LA, Perez-Gutthann S, et al. Hormone replacement therapy and incidence of acute myocardial infarction: a population-based nested case-control study. Circulation. 2000;101:2572-2578.

37. Viscoli CM, Brass LM, Kernan WN, et al. A clinical trial of estrogenreplacement therapy after ischemic stroke. $N$ Engl J Med. 2001;345:1243-1249.

38. Waters DD, Alderman EL, Hsia J, et al. Effects of hormone replacement therapy and antioxidant vitamin supplements on coronary atherosclerosis in postmenopausal women: a randomized controlled trial. JAMA. 2002;288:2432-2440.

39. Wilson PW, Garrison RJ, Castelli WP. Postmenopausal estrogen use, cigarette smoking, and cardiovascular morbidity in women over 50: the Framingham study. N Engl J Med. 1985;313:1038-1043.

40. Wolf PH, Madans JH, Finucane FF, et al. Reduction of cardiovascular disease-related mortality among postmenopausal women who use hormones: evidence from a national cohort. Am J Obstet Gynecol. 1991;164:489-494.

41. Risks and benefits of estrogen plus progestin in healthy postmenopausal women: principal results from the Women's Health Initiative randomized controlled trial. Writing group for the Women's Health Initiative investigators. JAMA. 2002;288:321-333.

\section{Meta-Analyses}

1. Barrett-Connor E, Grady D. Hormone replacement therapy, heart disease, and other considerations. Annu Rev Public Health. 1998;19:55-72.

2. Grady D, Rubin SM, Petitti DB, et al. Hormone therapy to prevent disease and prolong life in postmenopausal women. Ann Intern Med. 1992;117:1016-1037.

3. Herrington DM, Klein KP. Randomized clinical trials of hormone replacement therapy for treatment or prevention of cardiovascular disease: a review of the findings. Atherosclerosis. 2003;166:203-212.

4. Humphrey LL, Chan BK, Sox HC. Postmenopausal hormone replacement therapy and the primary prevention of cardiovascular disease. Ann Intern Med. 2002;137:273-284.

5. Stampfer MJ, Colditz GA. Estrogen replacement therapy and coronary heart disease: a quantitative assessment of the epidemiologic evidence. Prev Med. 1991;20:47-63.

\section{Diet Modification}

1. Al-Delaimy WK, Rimm E, Willett WC, et al. A prospective study of calcium intake from diet and supplements and risk of ischemic heart disease among men. Am J Clin Nutr. 2003;77:814-818.

2. Appleby PN, Thorogood M, Mann JI, et al. The Oxford Vegetarian Study: an overview. Am J Clin Nutr. 1999;70(3 suppl):525S-531S.
3. Arts IC, Jacobs DR, Harnack LJ, et al. Dietary catechins in relation to coronary heart disease death among postmenopausal women. Epidemiology. 2001;12:668-675.

4. Ascherio A, Willett WC, Rimm EB, et al. Dietary iron intake and risk of coronary disease among men. Circulation. 1994;89:969-974.

5. Ascherio A, Rimm EB, Stampfer MJ, et al. Dietary intake of marine n-3 fatty acids, fish intake, and the risk of coronary disease among men. N Engl J Med. 1995;332:977-982.

6. Ascherio A, Rimm EB, Giovannucci EL, et al. Dietary fat and risk of coronary heart disease in men: cohort follow up study in the United States. BMJ. 1996;313:84-90.

7. Bazzano LA, He J, Ogden LG, et al. Legume consumption and risk of coronary heart disease in US men and women: NHANES I epidemiologic follow-up study. Arch Intern Med. 2001;161:2573-2578.

8. Bazzano LA, He J, Ogden LG, et al. Fruit and vegetable intake and risk of cardiovascular disease in US adults: the first National Health and Nutrition Examination Survey epidemiologic follow-up study. Am J Clin Nutr. 2002;76:93-99.

9. Burr ML, Butland BK. Heart disease in British vegetarians. Am J Clin Nutr. 1988;48(3 suppl):830-832.

10. Daviglus ML, Stamler J, Orencia AJ, et al. Fish consumption and the 30-year risk of fatal myocardial infarction. $N$ Engl J Med. 1997;336:1046-1053.

11. De Lorgeril M, Renaud S, Mamelle N, et al. Mediterranean alpha-linolenic acid-rich diet in secondary prevention of coronary heart disease. Lancet. 1994;343:1454-1459.

12. De Lorgeril M, Salen P, Martin JL, et al. Mediterranean diet, traditional risk factors, and the rate of cardiovascular complications after myocardial infarction: final report of the Lyon Diet Heart Study. Circulation. 1999;99:779-785.

13. Ellsworth JL, Kushi LH, Folsom AR. Frequent nut intake and risk of death from coronary heart disease and all causes in postmenopausal women: the Iowa Women's Health Study. Nutr Metab Cardiovasc Dis. 2001;11:372-377.

14. Elwood PC, Fehily AM, Ising H, et al. Dietary magnesium does not predict ischemic heart disease in the Caerphilly cohort. Eur J Clin Nutr. 1996;50:694-697.

15. Esrey KL, Joseph L, Grover SA. Relationship between dietary intake and coronary heart disease mortality: lipid research clinics prevalence follow-up study. J Clin Epidemiol. 1996;49:211-216.

16. Fehily AM, Yarnell JW, Sweetnam PM, et al. Diet and incident ischemic heart disease: the Caerphilly study. Br J Nutr. 1993;69:303-314.

17. Fraser GE, Sabate J, Beeson WL, et al. A possible protective effect of nut consumption on risk of coronary heart disease: the Adventist Health Study. Arch Intern Med. 1992;152:1416-1424.

18. Gartside PS, Glueck CJ. The important role of modifiable dietary and behavioral characteristics in the causation and prevention of coronary heart disease hospitalization and mortality: the prospective NHANES I follow-up study. J Am Coll Nutr. 1995;14:71-79.

19. Gartside PS, Wang P, Glueck CJ. Prospective assessment of coronary heart disease risk factors: the NHANES I epidemiologic follow-up study (NHEFS) 16-year follow-up. J Am Coll Nutr. 1998;17:263-269.

20. Gaziano JM, Manson JE, Branch LG, et al. A prospective study of consumption of carotenoids in fruits and vegetables and decreased cardiovascular mortality in the elderly. Ann Epidemiol. 1995;5:255-260.

21. Geleijnse JM, Launer LJ, Van der Kuip DA, et al. Inverse association of tea and flavonoid intakes with incident myocardial infarction: the Rotterdam Study. Am J Clin Nutr. 2002;75:880-886.

22. Gillum RF, Mussolino M, Madans JH. The relation between fish consumption, death from all causes, and incidence of coronary heart disease. the NHANES I epidemiologic follow-up study. J Clin Epidemiol. 2000;53:237-244.

23. Hertog MG, Feskens EJ, Hollman PC, et al. Dietary antioxidant flavonoids and risk of coronary heart disease: the Zutphen Elderly Study. Lancet. 1993;342:1007-1011.

24. Hu FB, Stampfer MJ, Manson JE, et al. Dietary fat intake and the risk of coronary heart disease in women. N Engl J Med. 1997;337:1491-1499.

25. Hu FB, Stampfer MJ, Manson JE, et al. Frequent nut consumption and risk of coronary heart disease in women: prospective cohort study. BMJ. 1998;317:1341-1345.

26. Hu FB, Stampfer MJ, Manson JE, et al. Dietary protein and risk of ischemic heart disease in women. Am J Clin Nutr. 1999;70:221-227.

27. Hu FB, Stampfer MJ, Manson JE, et al. Dietary intake of alpha-linolenic acid and risk of fatal ischemic heart disease among women: including commentary by Connor WE. Am J Clin Nutr. 1999;69:890-897, 827-828. 
28. Hu FB, Stampfer MJ, Manson JE, et al. Dietary saturated fats and their food sources in relation to the risk of coronary heart disease in women: Nurses' Health Study. Am J Clin Nutr. 1999;70:1001-1008.

29. Hu FB, Rimm EB, Stampfer MJ, et al. Prospective study of major dietary patterns and risk of coronary heart disease in men. Am J Clin Nutr. 2000;72:912-921.

30. Hu FB, Cho E, Rexrode KM, et al. Fish and long-chain omega-3 fatty acid intake and risk of coronary heart disease and total mortality in diabetic women. Circulation. 2003;107:1852-1857.

31. Joshipura KJ, Hu FB, Manson JE, et al. The effect of fruit and vegetable intake on risk for coronary heart disease. Ann Intern Med. 2001;134:1106-1114.

32. Key TJ, Thorogood M, Appleby PN, et al. Dietary habits and mortality in 11,000 vegetarians and health conscious people: results of a 17 year follow up. BMJ. 1996;313:775-779.

33. Klipstein-Grobusch K, Geleijnse JM, den Breeijen JH, et al. Dietary antioxidants and risk of myocardial infarction in the elderly: the Rotterdam Study. Am J Clin Nutr. 1999;69:261-266.

34. Klipstein-Grobusch K, Grobbee DE, den Breeijen JH, et al. Dietary iron and risk of myocardial infarction in the Rotterdam Study. Am J Epidemiol. 1999;149:421-428.

35. Knekt P, Reunanen A, Jarvinen R, et al. Antioxidant vitamin intake and coronary mortality in a longitudinal population study. Am J Epidemiol. 1994;139:1180-1189.

36. Knekt P, Jarvinen R, Reunanen A, et al. Flavonoid intake and coronary mortality in Finland: a cohort study. BMJ. 1996;312:478-481.

37. Knekt P, Kumpulainen J, Jarvinen R, et al. Flavonoid intake and risk of chronic diseases. Am J Clin Nutr. 2002;76:560-568.

38. Kromhout D, Bosschieter EB, de Lezenne-Coulander C. The inverse relation between fish consumption and 20-year mortality from coronary heart disease. N Engl J Med. 1985;312:1205-1209.

39. Kushi LH, Lew RA, Stare FJ, et al. Diet and 20-year mortality from coronary heart disease: the Ireland-Boston Diet-Heart Study. N Engl J Med. 1985;312:811-818.

40. Kushi LH, Folsom AR, Prineas RJ, et al. Dietary antioxidant vitamins and death from coronary heart disease in postmenopausal women. $N$ Engl J Med. 1996;334:1156-1162.

41. Lapidus L, Andersson H, Bengtsson C, et al. Dietary habits in relation-incidence of cardiovascular disease and death in women: a 12-year follow-up of participants in the population study of women in Gothenburg, Sweden. Am J Clin Nutr. 1986;44:444-448.

42. Leren P. Prevention of coronary heart disease: some results from the Oslo secondary and primary intervention studies. J Am Coll Nutr. 1989;8:407-410.

43. Liu S, Stampfer MJ, Hu FB, et al. Whole-grain consumption and risk of coronary heart disease: results from the Nurses' Health Study: including commentary by Anderson JW and Hanna TJ. Am J Clin Nutr. 1999;70: 412-419, 307-308.

44. Liu S, Manson JE, Lee I, et al. Fruit and vegetable intake and risk of cardiovascular disease: the Women's Health Study. Am J Clin Nutr. 2000;72:922-928.

45. Liu S, Willett WC, Stampfer MJ, et al. A prospective study of dietary glycemic load, carbohydrate intake, and risk of coronary heart disease in US women. Am J Clin Nutr. 2000;71:1455-1461.

46. Malaviarahchi D, Veugelers PJ, Yip AM, et al. Dietary iron as a risk factor for myocardial infarction: public health considerations for Nova Scotia. Can J Public Health. 2002;93:267-270.

47. Mann JI, Appleby PN, Key TJ, et al. Dietary determinants of ischemic heart disease in health conscious individuals. Heart. 1997;78:450-455.

48. McCullough ML, Feskanich D, Stampfer MJ, et al. Adherence to the Dietary Guidelines for Americans and risk of major chronic disease in women. Am J Clin Nutr. 2000;72:1214-1222.

49. Morris MC, Manson JE, Rosner B, et al. Fish consumption and cardiovascular disease in the physicians' health study: a prospective study. Am J Epidemiol. 1995;142:166-175.

50. Mozaffarian D, Lemaitre RN, Kuller LH, et al. Cardiac benefits of fish consumption may depend on the type of fish meal consumed: the Cardiovascular Health Study. Circulation. 2003;107:1372-1377.

51. Oomen CM, Feskens EJ, Rasanen L, et al. Fish consumption and coronary heart disease mortality in Finland, Italy, and The Netherlands. Am J Epidemiol. 2000;151:999-1006.

52. Osganian SK, Stampfer MJ, Rimm E, et al. Dietary carotenoids and risk of coronary artery disease in women. Am J Clin Nutr. 2003;77:1390-1399.
53. Osler M, Andreasen AH, Hoidrup S. No inverse association between fish consumption and risk of death from all-causes, and incidence of coronary heart disease in middle-aged, Danish adults. J Clin Epidemiol. 2003;56:274-279.

54. Pietinen $\mathrm{P}$, Ascherio A, Korhonen $\mathrm{P}$, et al. Intake of fatty acids and risk of coronary heart disease in a cohort of Finnish men: the Alpha-Tocopherol, Beta-Carotene Cancer Prevention Study. Am J Epidemiol. 1997; 145:876-887.

55. Reunanen A, Takkunen H, Knekt P, et al. Body iron stores, dietary iron intake and coronary heart disease mortality. J Intern Med. 1995;238:223-230.

56. Rimm EB, Ascherio A, Giovannucci E, et al. Vegetable, fruit, and cereal fiber intake and risk of coronary heart disease among men. JAMA. 1996;275:447-451.

57. Rimm EB, Katan MB, Ascherio A, et al. Relation between intake of flavonoids and risk for coronary heart disease in male health professionals. Ann Intern Med. 1996;125:384-389.

58. Rissanen TH, Voutilainen S, Virtanen JK, et al. Low intake of fruits, berries and vegetables is associated with excess mortality in men: the Kuopio Ischemic Heart Disease Risk Factor (KIHD) study. J Nutr. 2003;133:199-204.

59. Shekelle RB, Stamler J. Dietary cholesterol and ischemic heart disease. Lancet. 1989;1:1177-1179.

60. Singh RB, Dubnov G, Niaz MA, et al. Effect of an Indo-Mediterranean diet on progression of coronary artery disease in high risk patients (Indo-Mediterranean Diet Heart Study): a randomized single-blind trial. Lancet. 2002;360:1455-1461.

61. Stampfer MJ, Hu FB, Manson JE, et al. Primary prevention of coronary heart disease in women through diet and lifestyle. $N$ Engl J Med. 2000;343:16-22.

62. Suh I, Shaten BJ, Cutler JA, et al. Alcohol use and mortality from coronary heart disease: the role of high-density lipoprotein cholesterol. Multiple Risk Factor Intervention Trial research group. Ann Intern Med. 1992;116:881-887.

63. Thorogood M, Mann J, Appleby P, et al. Risk of death from cancer and ischemic heart disease in meat and non-meat eaters. BMJ. 1994;308:1667-1670.

64. Trichopoulou A, Costacou T, Bamia C, et al. Adherence to a Mediterranean diet and survival in a Greek population. $N$ Engl $\mathrm{J} \mathrm{Med}$. 2003;348:2599-2608.

65. Tsugane S, Fahey MT, Sasaki S, et al. Alcohol consumption and all-cause and cancer mortality among middle-aged Japanese men: seven-year follow-up of the JPHC study Cohort I. Japan Public Health Center. Am J Epidemiol. 1999;150:1201-1207.

66. Voutilainen S, Rissanen TH, Virtanen J, et al. Low dietary folate intake is associated with an excess incidence of acute coronary events: the Kuopio Ischemic Heart Disease Risk Factor study. Circulation. 2001;103:2674-2680.

67. Willett WC, Stampfer MJ, Manson JE, et al. Intake of trans fatty acids and risk of coronary heart disease among women. Lancet. 1993;341:581-585.

68. Yuan JM, Ross RK, Gao YT, et al. Fish and shellfish consumption in relation to death from myocardial infarction among men in Shanghai, China. Am J Epidemiol. 2001;154:809-816.

\section{Meta-Analyses}

1. Danesh J, Appleby P. Coronary heart disease and iron status: meta-analyses of prospective studies. Circulation. 1999;99:852-854.

2. Ebrahim S, Smith GD. Systematic review of randomized controlled trials of multiple risk factor interventions for preventing coronary heart disease. BMJ. 1997;314:1666-1674.

3. Law MR, Morris JK. By how much does fruit and vegetable consumption reduce the risk of ischemic heart disease?. Eur J Clin Nutr. 1998;52:549-556.

4. Law MR, Morris JK, Wald NJ. Environmental tobacco smoke exposure and ischemic heart disease: an evaluation of the evidence. BMJ. 1997;315:973-980.

\section{Warfarin in Atrial Fibrillation}

1. The effect of low-dose warfarin on the risk of stroke in patients with nonrheumatic atrial fibrillation: the Boston Area Anticoagulation Trial for Atrial Fibrillation investigators. N Engl J Med. 1990;323:1505-1511. 
2. Connolly SJ, Laupacis A, Gent M, et al. Canadian Atrial Fibrillation Anticoagulation (CAFA) study. J Am Coll Cardiol. 1991;18:349-355.

3. Secondary prevention in non-rheumatic atrial fibrillation after transient ischemic attack or minor stroke: EAFT (European Atrial Fibrillation Trial) study group. Lancet. 1993;342:1255-1262.

4. Ezekowitz MD, Bridgers SL, James KE, et al. Warfarin in the prevention of stroke associated with nonrheumatic atrial fibrillation: Veterans Affairs Stroke Prevention in Nonrheumatic Atrial Fibrillation Investigators. N Engl J Med. 1992;327:1406-1412.

5. Gullov AL, Koefoed BG, Petersen P, et al. Fixed minidose warfarin and aspirin alone and in combination versus adjusted-dose warfarin for stroke prevention in atrial fibrillation: Second Copenhagen Atrial Fibrillation, Aspirin, and Anticoagulation Study. Arch Intern Med. 1998;158:1513-1521.

6. Morocutti C, Amabile G, Fattapposta F, et al. Indobufen versus warfarin in the secondary prevention of major vascular events in nonrheumatic atrial fibrillation. Stroke. 1997;28:1015-1021.

7. Pengo V, Zasso A, Barbero F, et al. Effectiveness of fixed minidose warfarin in the prevention of thromboembolism and vascular death in nonrheumatic atrial fibrillation. Am J Cardiol. 1998;82:433-437.

8. Petersen P, Boysen G, Godtfredsen J, et al. Placebo-controlled, randomized trial of warfarin and aspirin for prevention of thromboembolic complications in chronic atrial fibrillation: the Copenhagen AFASAK study. Lancet. 1989;1:175-179.

9. Stroke Prevention in Atrial Fibrillation Study: final results. Stroke Prevention in Atrial Fibrillation investigators. Circulation. 1991;84:527-539.

10. Warfarin versus aspirin for prevention of thromboembolism in atrial fibrillation: Stroke Prevention in Atrial Fibrillation II study. Stroke Prevention in Atrial Fibrillation investigators. Lancet ( $N$ Am Edition). 1994;343:687-691.

11. Adjusted-dose warfarin versus low-intensity, fixed-dose warfarin plus aspirin for high-risk patients with atrial fibrillation: Stroke Prevention in Atrial Fibrillation III randomized clinical trial. Stroke Prevention in Atrial Fibrillation investigators. Lancet. 1996;348:633-638.

\section{Meta-Analyses}

1. Evans A, Kalra L. Are the results of randomized controlled trials on anticoagulation in patients with atrial fibrillation generalizable to clinical practice? Arch Intern Med. 2001;161:1443-1447.

2. Ezekowitz MD, Levine JA. Preventing stroke in patients with atrial fibrillation. JAMA. 1999;281:1830-1835.

3. Green CJ, Hadorn DC, Bassett K, et al. Anticoagulation in chronic nonvalvular atrial fibrillation: a critical appraisal and meta-analysis. Can J Cardiol. 1997;13:811-815.

4. Hart RG, Benavente O, McBride R, et al. Antithrombotic therapy to prevent stroke in patients with atrial fibrillation: a meta-analysis. Ann Intern Med. 1999;131:492-501.

5. Segal JB, McNamara RL, Miller MR, et al. Anticoagulants or antiplatelet therapy for non-rheumatic atrial fibrillation and flutter. Oxford: The Cochrane Library; 2003;(2):CD001938.

6. Taylor FC, Cohen H, Ebrahim S. Systematic review of long term anticoagulation or antiplatelet treatment in patients with non-rheumatic atrial fibrillation. BMJ. 2001;322:321-326.

\section{Aspirin for Primary Prevention}

1. De Gaetano G. Low-dose aspirin and vitamin E in people at cardiovascular risk: a randomized trial in general practice: collaborative group of the Primary Prevention Project. Lancet. 2001;357:89-95. Erratum in: Lancet. 2001;357:1134.

2. Garcia Rodriguez LA, Varas C, Patrono C. Differential effects of aspirin and non-aspirin nonsteroidal antiinflammatory drugs in the primary prevention of myocardial infarction in postmenopausal women. Epidemiology. 2000;11:382-387.

3. Hammond EC, Garfinkel L. Aspirin and coronary heart disease: findings of a prospective study. BMJ. 1975;2:269-271.

4. Hansson L, Zanchetti A, Carruthers SG, et al. Effects of intensive bloodpressure lowering and low-dose aspirin in patients with hypertension: principal results of the Hypertension Optimal Treatment (HOT) randomized trial. HOT study group. Lancet. 1998;351:1755-1762.

5. Manson JE, Grobbee DE, Stampfer MJ, et al. Aspirin in the primary prevention of angina pectoris in a randomized trial of United States physicians. Am J Med. 1990;89:772-776.
6. Manson JE, Stampfer MJ, Colditz GA, et al. A prospective study of aspirin use and primary prevention of cardiovascular disease in women. JAMA. 1991;266:521-527.

7. Thrombosis prevention trial: randomized trial of low-intensity oral anticoagulation with warfarin and low-dose aspirin in the primary prevention of ischemic heart disease in men at increased risk. The Medical Research Council's General Practice Research Framework. Lancet. 1998;351:233-241.

8. Paganini-Hill A, Chao A, Ross RK, et al. Aspirin use and chronic diseases: a cohort study of the elderly. BMJ. 1989;299:1247-1250.

9. Peters JG, Shamire RM. Effects of aspirin dose when used alone or in combination with clopidogrel in patients with acute coronary syndromes: observations from the Clopidogrel in Unstable angina-prevent Recurrent Events (CURE) study. The Clopidogrel in Unstable angina-prevent Recurrent Events (CURE) trial investigators. Circulation. 2003;108:1682-1687.

10. Peto R, Gray R, Collins R, et al. Randomized trial of prophylactic daily aspirin in British male doctors. $\mathrm{Br}$ Med $J$ (Clin Res Ed). 1988;296:313-316.

11. Final report on the aspirin component of the ongoing Physicians' Health Study: steering committee of the Physicians' Health Study research group. N Engl J Med. 1989;321:129-135.

\section{Meta-Analyses}

1. Collaborative meta-analysis of randomized trials of antiplatelet therapy for prevention of death, myocardial infarction, and stroke in high risk patients: Antithrombotic Trialists' Collaboration. BMJ. 2002;324:71-86.

2. Eidelman RS, Herbert PR, Weisman SM, et al. An update on aspirin in the primary prevention of cardiovascular disease. Arch Intern Med. 2003;163:2006-2010.

3. Hayden M, Pignone M, Phillips C, et al. Aspirin for the primary prevention of cardiovascular events: a summary of the evidence for the US Preventive Services Task Force. Ann Intern Med. 2002;136:161-172.

4. Sanmuganathan PS, Ghahramani P, Jackson PR, et al. Aspirin for primary prevention of coronary heart disease: safety and absolute benefit related to coronary risk derived from meta-analysis of randomized trials. Heart. 2001;85:265-271.

\section{Therapy for Depression}

1. Berkman LF, Blumenthal J, Burg M, et al. Effects of treating depression and low perceived social support on clinical events after myocardial infarction: the Enhancing Recovery in Coronary Heart Disease Patients (ENRICHD) randomized trial. JAMA. 2003;289:3106-3116.

2. Glassman AH, O'Connor CM, Califf RM, et al. Sertraline treatment of major depression in patients with acute MI or unstable angina. JAMA. 2002;288:701-709.

\section{Antioxidant Supplementation}

1. Boaz M, Smetana S, Weinstein T, et al. Secondary prevention with antioxidants of cardiovascular disease in endstage renal disease (SPACE): randomized placebo-controlled trial. Lancet. 2000;356:1213-1218.

2. Dietary supplementation with n-3 polyunsaturated fatty acids and vitamin E after myocardial infarction: results of the GISSI-Prevenzione trial. Gruppo Italiano per lo Studio della Sopravvivenza nell'Infarto miocardico. Lancet. 1999;354:447-455.

3. MRC/BHF Heart Protection Study of antioxidant vitamin supplementation in 20,536 high-risk individuals: a randomized placebo-controlled trial. Heart Protection Study collaborative group. Lancet. 2002;360:23-33.

4. Klipstein-Grobusch K, Geleijnse JM, den Breeijen JH, et al. Dietary antioxidants and risk of myocardial infarction in the elderly: the Rotterdam Study. Am J Clin Nutr. 1999;69:261-266.

5. Kushi LH, Folsom AR, Prineas RJ, et al. Dietary antioxidant vitamins and death from coronary heart disease in postmenopausal women. $\mathrm{N} \mathrm{Engl}$ J Med. 1996;334:1156-1162.

6. Lonn E, Yusuf S, Hoogwerf B, et al. Effects of vitamin E on cardiovascular and microvascular outcomes in high-risk patients with diabetes: results of the HOPE study and MICRO-HOPE substudy. Diabetes Care. 2002;25:1919-1927.

7. Losonczy KG, Harris TB, Havlik RJ. Vitamin E and vitamin C supplement use and risk of all-cause and coronary heart disease mortality in older persons: the Established Populations for Epidemiologic Studies of the Elderly. Am J Clin Nutr. 1996;64:190-196. 
8. Marchioli R, Schweiger C, Tavazzi L, et al. Efficacy of n-3 polyunsaturated fatty acids after myocardial infarction: results of GISSIPrevenzione trial. Gruppo Italiano per lo Studio della Sopravvivenza nell'Infarto Miocardico. Lipids. 2001;36:S119-S126.

9. Rapola JM, Virtamo J, Ripatti S, et al. Randomized trial of alpha-tocopherol and beta-carotene supplements on incidence of major coronary events in men with previous myocardial infarction. Lancet. 1997;349:1715-1720.

10. Rapola JM, Virtamo J, Ripatti S, et al. Effects of alpha tocopherol and beta carotene supplements on symptoms, progression, and prognosis of angina pectoris. Heart. 1998;79:454-458.

11. Rimm EB, Stampfer MJ, Ascherio A, et al. Vitamin E consumption and the risk of coronary heart disease in men. $N$ Engl J Med. 1993;328:1450-1456.

12. Stampfer MJ, Hennekens CH, Manson JE, et al. Vitamin E consumption and the risk of coronary disease in women. $N$ Engl J Med. 1993;328:1444-1449.

13. Stephens NG, Parsons A, Schofield PM, et al. Randomized controlled trial of vitamin $\mathrm{E}$ in patients with coronary disease: Cambridge Heart Antioxidant Study (CHAOS). Lancet. 1996;347:781-786.

14. Virtamo J, Rapola JM, Ripatti S, et al. Effect of vitamin E and beta carotene on the incidence of primary nonfatal myocardial infarction and fatal coronary heart disease. Arch Intern Med. 1998;158:668-675.

15. Waters DD, Alderman EL, Hsia J, et al. Effects of hormone replacement therapy and antioxidant vitamin supplements on coronary atherosclerosis in postmenopausal women: a randomized controlled trial. JAMA. 2002;288:2432-2440.

16. Yusuf S, Dagenais G, Pogue J, et al. Vitamin E supplementation and cardiovascular events in high-risk patients: the Heart Outcomes Prevention Evaluation study investigators. $N$ Engl J Med. 2000;342:154-160.

\section{Omega-3 Fatty Acid Supplementation}

1. Ascherio A, Rimm EB, Giovannucci EL, et al. Dietary fat and risk of coronary heart disease in men: cohort follow up study in the United States. BMJ. 1996;313:84-90.

2. De Lorgeril M, Renaud S, Mamelle N, et al. Mediterranean alpha-linolenic acid-rich diet in secondary prevention of coronary heart disease. Lancet. 1994;343:1454-1459.

3. Dietary supplementation with $n-3$ polyunsaturated fatty acids and vitamin E after myocardial infarction: results of the GISSI-Prevenzione trial. Gruppo Italiano per lo Studio della Sopravvivenza nell'Infarto miocardico. Lancet. 1999;354:447-455.

4. Hu FB, Cho E, Rexrode KM, et al. Fish and long-chain omega-3 fatty acid intake and risk of coronary heart disease and total mortality in diabetic women. Circulation. 2003;107:1852-1857.

5. Marchioli R, Schweiger C, Tavazzi L, et al. Efficacy of n-3 polyunsaturated fatty acids after myocardial infarction: results of GISSI-
Prevenzione trial. Gruppo Italiano per lo Studio della Sopravvivenza nell'Infarto Miocardico. Lipids. 2001;36:S119-S126.

6. Marchioli R, Barzi F, Bomba E, et al. Early protection against sudden death by $n-3$ polyunsaturated fatty acids after myocardial infarction: time-course analysis of the results of the Gruppo Italiano per lo Studio della Sopravvivenza nell'Infarto Miocardico (GISSI)-Prevenzione. Circulation. 2002;105:1897-1903.

7. Nilsen DW, Albrektsen G, Landmark K, et al. Effects of a high-dose concentrate of n-3 fatty acids or corn oil introduced early after an acute myocardial infarction on serum triacylglycerol and HDL cholesterol. Am J Clin Nutr. 2001;74:50-56.

8. Singh RB, Niaz MA, Sharma JP, et al. Randomized, double-blind, placebo-controlled trial of fish oil and mustard oil in patients with suspected acute myocardial infarction: the Indian experiment of infarct survival. Cardiovasc Drugs Ther. 1997;11:485-491.

\section{Meta-Analyses}

1. Bucher HC, Hengstler P, Schindler C, et al. N-3 polyunsaturated fatty acids in coronary heart disease: a meta-analysis of randomized controlled trials. Am J Med. 2002;112:298-304.

2. Gapinski JP, VanRuiswyk JV, Heudebert GR, et al. Preventing restenosis with fish oils following coronary angioplasty: a meta-analysis. Arch Intern Med. 1993;153:1595-1601.

\section{Folic Acid Supplementation}

1. Liem A, Reynierse-Buitenwerf GH, Zwinderman AH, et al. Secondary prevention with folic acid: effects on clinical outcomes. $J$ Am Coll Cardiol. 2003;41:2105-2113.

2. Schnyder G, Roffi M, Pin R, et al. Decreased rate of coronary restenosis after lowering of plasma homocysteine levels. $N$ Engl J Med. 2001;345:1593-1600.

3. Schnyder G, Roffi M, Flammer Y, et al. Effect of homocysteine-lowering therapy with folic acid, vitamin B12, and vitamin B6 on clinical outcome after percutaneous coronary intervention: the Swiss Heart study: a randomized controlled trial. JAMA. 2002;288:973-979.

\section{Meta-Analysis}

1. Taylor BV, Oudit GY, Evans M. Homocysteine, vitamins, and coronary artery disease: comprehensive review of the literature. Can Fam Physician. 2000;46:2236-45 treatment of high blood cholesterol in adults (Adult Treatment Panel III). JAMA. 2001;285:2486-2497.

KeY Words: AHA Scientific Statements cardiovascular diseases $\square$ risk factors 


\section{Evidence-Based Guidelines for Cardiovascular Disease Prevention in Women}

Lori Mosca, Lawrence J. Appel, Emelia J. Benjamin, Kathy Berra, Nisha Chandra-Strobos, Rosalind P. Fabunmi, Deborah Grady, Constance K. Haan, Sharonne N. Hayes, Debra R. Judelson, Nora L. Keenan, Patrick McBride, Suzanne Oparil, Pamela Ouyang, Mehmet C. Oz, Michael E. Mendelsohn, Richard C. Pasternak, Vivian W. Pinn, Rose Marie Robertson, Karin Schenck-Gustafsson, Cathy A. Sila, Sidney C. Smith, Jr, George Sopko, Anne L. Taylor, Brian W. Walsh, Nanette K. Wenger and Christine L. Williams

\section{Circulation. 2004;109:672-693; originally published online February 4, 2004;} doi: 10.1161/01.CIR.0000114834.85476.81

Circulation is published by the American Heart Association, 7272 Greenville Avenue, Dallas, TX 75231

Copyright () 2004 American Heart Association, Inc. All rights reserved.

Print ISSN: 0009-7322. Online ISSN: 1524-4539

The online version of this article, along with updated information and services, is located on the World Wide Web at:

http://circ.ahajournals.org/content/109/5/672

Data Supplement (unedited) at:

http://circ.ahajournals.org/content/suppl/2004/02/09/01.CIR.0000114834.85476.81.DC1

\footnotetext{
Permissions: Requests for permissions to reproduce figures, tables, or portions of articles originally published in Circulation can be obtained via RightsLink, a service of the Copyright Clearance Center, not the Editorial Office. Once the online version of the published article for which permission is being requested is located, click Request Permissions in the middle column of the Web page under Services. Further information about this process is available in the Permissions and Rights Question and Answer document.
}

Reprints: Information about reprints can be found online at: http://www.lww.com/reprints

Subscriptions: Information about subscribing to Circulation is online at: http://circ.ahajournals.org//subscriptions/ 